PRESERVATION OF AUTOGENIC PROCESSES AND ALLOGENIC FORCINGS

WITHIN SET-SCALE AEOLIAN ARCHITECTURE II: THE SCOUR-AND-FILL

DOMINATED JURASSIC PAGE SANDSTONE, ARIZONA, USA

\begin{abstract}
RUNNING TITLE: AUTOGENIC PROCESSES AND ALLOGENIC FORCINGS IN AEOLIAN STRATIGRAPHY II

BENJAMIN T. CARDENAS ${ }^{1}$, GARY KOCUREK ${ }^{1}$, DAVID MOHRIG ${ }^{1}$, TRAVIS SWANSON$^{2}$, CORY M. HUGHES ${ }^{1 *}$, and SARAH C. BROTHERS ${ }^{1^{* *}}$

${ }^{1}$ Jackson School of Geosciences, University of Texas at Austin, Austin, TX, USA

${ }^{2}$ Department of Earth Science, Rice University, Houston, TX, USA

*now at Department of Geology, Western Washington University, Bellingham, WA, USA

${ }^{* *}$ now at National Academies Space Studies Board, Washington, D.C., USA
\end{abstract}

Corresponding Author Email: benjamin.cardenas@utexas.edu

Key Words: aeolian, dune, sedimentology, autogenic, allogenic

THIS IS A NON-PEER REVIEWED PRE-PRINT SUBMITTED TO EARTHARVIX AND

UNDER REVIEW AT THE JOURNAL OF SEDIMENTARY RESEARCH

Figures: 14

References: 72

Supplemental Figures: 3

Supplemental Tables: 1 


\section{ABSTRACT}

The stratigraphic architecture of aeolian sandstones is thought to record signals

originating from both autogenic dune behavior and allogenic environmental boundary conditions

4 within which the dune field evolves. Mapping of outcrop-scale surfaces and sets of cross-strata

5 between these surfaces for the Jurassic Page Sandstone near Page, Arizona, USA, demonstrates

6 that the stratigraphic signature of autogenic behavior is captured by variable scour depths and

7 subsequent fillings, whereas the dominant signatures of allogenic boundary conditions are

8 associated with antecedent surface topography and variable water-table elevations. At the study

9 area, the Page Sandstone is $\sim 60 \mathrm{~m}$ thick and is separated from the underlying Navajo Sandstone

10 by the J-2 regional unconformity with meters of relief. Thin, climbing sets of cross-strata of the

11 basal Page representing early dune-field accumulations fill J-2 depressions. In contrast, the

12 overlying lower and middle Page consist of cross-strata that are one to a few meters thick, and

13 packaged between outcrop-scale bounding surfaces. These bounding surfaces have been

14 previously correlated to high stand deposits of the adjacent Carmel sea and at this site possess

15 meters of erosional relief produced by dune scour. Notably absent within packages of cross-strata

16 bounded by these outcrop-scale surfaces are strata of early dune-field accumulations, any

17 interdune deposits, and climbing-dune strata. Instead, these packages preserve a scour-and-fill

18 architecture created by large migrating dunes migrating within a dry, mature, dune field

19 undergoing negligible bed aggradation. Any record of early phases of dune-field construction for

20 the lower and middle Page are interpreted to have been cannibalized by the deepest scours of

21 later, large dunes. Interpretations are independently supported by the relatively large coefficients

22 of variation in lower and middle Page set thicknesses, which are consistent with set production

23 by successive deepest trough scours, and the relatively low coefficient of variation for the 
24 depression-filling basal Page sets consistent with a significant component of bed aggradation.

25 Numerical modeling presented here and more completely in the companion paper demonstrates

26 how this cannibalization of early-phase stratigraphy is an expected outcome of autogenic dune-

27 growth processes, and that early-phase strata can be preserved within antecedent depressions.

28 Relative rise of the inland water table from basin subsidence and Carmel sea level forced

29 preservation of multiple stacked packages composed of scour-and-fill architecture. Without these 30 allogenic forcings, the Page would be little more than an erosional surface.

\section{INTRODUCTION}

Aeolian dune fields develop over time as a result of autogenic processes that occur within a set of environmental (allogenic) boundary conditions. Autogenic processes inherent to a field of migrating dunes include dune interactions (Werner 1995; Ewing and Kocurek 2010a; Kocurek et al. 2010; Gao et al. 2015a), dune deformation with migration (Pedersen et al. 2015; Swanson et al. 2016), and dune scour of the substrate (Paola and Borgman 1991; Bridge and Best 1997). Common allogenic boundary conditions for aeolian systems include the presence or absence of a near-surface water table (Crabaugh and Kocurek 1993; Kocurek and Havholm 1993), direction and magnitude of sediment-transporting winds (Rubin 1987; Rubin and Hunter 1987; Ping et al. 2014; Swanson et al. 2017), sediment availability (Courrech du Pont et al. 2014; Gao et al. 2015b), and geometry of the sediment source and basin shape (Ewing and Kocurek 2010b). The general trend in dune-field development is for many, small, closely spaced dunes to coalesce into fewer, larger, widely spaced dunes over time and space through constructive dune interactions (Ewing and Kocurek 2010a; Eastwood et al. 2011; Gao et al. 2015a; Day and Kocurek, 2018). Aeolian strata record these interaction kinematics (Brothers et al. 2017; Day and 
47 Kocurek 2017), and may potentially preserve strata associated with any phase of this

48 development. Conversely, the presence or absence of preserved accumulations associated with different developmental stages are useful data for interpreting the allogenic and autogenic forces

50 that led to its accumulation and preservation (Kocurek and Day 2017).

52 the collection of detailed field mapping and topographic measurements. Facies interpretations, 53 stratal architecture, and bounding surface topography are used to demonstrate that the Page sets 54 of cross-strata are dominated by a scour-and-fill architecture constructed by relatively large, 55 mature dunes. Moreover, this later-phase of dune construction cannibalized most strata that may 56 have accumulated during earlier phases of dune-field development, as well as having scoured 57 into underlying strata from previous constructional events. Even so, two examples of earlier 58 dune-field phases and their distinct cross-strata facies were preserved in local, pre-existing 59 topographic lows. Variable trough scour depth was the dominant autogenic control on preserved 60 stratigraphy, whereas antecedent topography and depth to water table are demonstrated to have 61 been the dominant allogenic controls on the architecture of the Page Sandstone. Interpretation 62 was aided by a numerical model coupling dune morphodynamics and stratigraphy, which is the 63 focus of the companion paper (Swanson et al. this issue). sandstones in the world (Blakey et al. 1983, 1988; Rodríguez-López et al. 2014), and literature

67 discussing the Page Sandstone is extensive. The Page Sandstone preserves a time series of NE68 SW trending dune fields situated between the Monument Upwarp and the Carmel inland sea 69 (Blakey et al. 1988; Riggs and Blakey 1993; Peterson 1994) (Fig. 1A) during the Middle 
Jurassic, 171.5-169.5 Ma (Blakey and Parnell 1995; Dickinson et al. 2010). Facies within the

71 Carmel Formation represent shallow marine, sabkha, and fluvial settings, and these intertongue

72 with aeolian Page accumulations over a belt $\sim 75 \mathrm{~km}$ wide running parallel to the paleocoastline

73 (Havholm et al. 1993; Blakey et al. 1996; Taggart et al. 2010). Intertonguing of the Carmel

74 coastal complex with the western portions of the Page Sandstone is interpreted to represent the

75 interplay of tectonic subsidence within the Utah-Idaho trough, changes in sediment supply, and

76 sea level (Blakey et al. 1996).

The Page Sandstone is separated from the underlying Navajo Sandstone by the J-2

78 surface, one of six regional unconformities formed across the greater Colorado Plateau during

79 the Jurassic (Pipiringos and O’Sullivan 1978). The J-2 surface near Page, Arizona, is

80 characterized by large polygonal fractures, diagenetic chert nodules, and meters of erosional

81 relief (Pipiringos and O’Sullivan 1978; Kocurek and Hunter 1986; Swezey 1991; Kocurek et al.

82 1991). The Page is overlain by the Carmel Formation, representing eastward progradation of the

83 Carmel fluvial and coastal complex (Blakey et al. 1996).

Previous work has produced hundreds of correlated vertical sections across the entirety of

85 the Page Sandstone (Capps 1990; Jones 1990; Havholm 1991; Kocurek et al. 1991; King 1992;

86 Havholm et al. 1993; Jones and Blakey 1993; Havholm and Kocurek 1994; Blakey et al. 1996).

87 The Page has been informally divided into a basal, lower, middle, and upper unit by Havholm et

88 al. (1993), and these divisions correlate with formal stratigraphic names used by Blakey et al.

89 (1996) (Fig. 1B). The informal units were defined using formation-scale, erosional bounding

90 surfaces. These surfaces are characterized by polygonal fractures, interpreted as having

91 developed in evaporite-cemented sand, and/or overlying wavy bedding interpreted as sabkha

92 deposits (Figs. 2, 3; Kocurek and Hunter 1986; Havholm et al. 1993; Havholm and Kocurek 
1994). Both of these features have been used as stratigraphic proxies for the paleo-water table

94 (i.e., “Stokes surfaces” of Fryberger et al. 1988; “super surfaces” of Kocurek 1988). Each of

95 these surfaces can be traced westward to where it is overlain by a transgressive tongue of the

96 Carmel (Havholm et al. 1993; Havholm and Kocurek 1994; Blakey et al. 1996) (Fig. 1B).

97 Because the Carmel transgressive tongues represent relative high stands of the Carmel sea, and

98 their correlative inland surfaces are marked by features associated with the water table, the

99 surfaces are interpreted to represent the elevation of the coastal water table, which rose in

100 response to the adjacent sea-level rise (Havholm and Kocurek 1994; Blakey et al. 1996; Kocurek

101 et al. 2001). The surfaces themselves are interpreted as having been formed by deflation down to

102 the water table during the high stands in sea level when sediment availability was limited.

103 Conversely, Page dune systems are thought to have developed during low stands in sea level that

104 provided greater sand availability. Each body of Page cross-strata bounded by interpreted

105 deflationary surfaces is therefore inferred to represent aeolian strata accumulated during a low

106 stand and preserved as a consequence of a rising continental water table that protected it from

107 wind-blown deflation. The thickness of a preserved accumulation reflects the cumulative effects

108 of subsidence and relative sea-level rise, as reflected in the continental water table (Havholm and

109 Kocurek 1994; Blakey et al. 1996).

Aeolian Stratification Types

The three basic stratification types that compose aeolian cross-strata are grainfall,

112 grainflow, and wind-ripple deposits (Hunter, 1977). We used the architecture of these

113 stratification types to interpret relative dune size from preserved sets of cross-strata. Grainfall

114 deposits form when saltating grains are directly deposited on the lee faces of dunes. Grainfall is

115 typically greatest immediately downwind of the brink and the deposition rate decreases down the 
116 lee face. As a result, the lee slope steepens until the deposit builds to the angle of initial yield, 117 triggering an avalanche, or grainflow (Allen 1970a; Hunter 1977; Kocurek and Dott 1981;

118 McDonald and Anderson, 1995; Nield et al. 2017). Grainflow deposits are primarily located

119 along portions of the lee face aligned close to perpendicular to the sediment-transporting wind 120 direction (Eastwood et al. 2012). Wind-ripple laminations form via wind-ripple migration and 121 aggradation along dune lee faces (Hunter 1977), particularly those segments obliquely oriented 122 to the regional wind direction (Eastwood et al. 2012). Commonly, aeolian cross-strata are composed of alternating packages of grainflow 124 deposits and wind-ripple laminations, representing either seasonal changes in wind direction 125 and/or changes in dune shape and crest orientation (Hunter and Rubin 1983). Because aeolian 126 sets of cross-strata typically represent only the basal portions of dune lee faces, grainfall deposits 127 are less frequently preserved in sets representing large dunes. Grainfall deposits are, however, 128 common in cross-strata representing small dunes, where the grainfall apron extended to the base 129 of the dunes (Kocurek and Dott 1981). The Page Sandstone exhibits all three stratification types, 130 and their typical arrangements within the range of set thicknesses are presented as Figures 4A to $131 \mathrm{C}$ and $5 \mathrm{~A}$ to $\mathrm{B}$.

\section{Aeolian set architecture}

The architecture of aeolian sets of cross-strata between outcrop-scale bounding surfaces 134 preserve a record of dune-field kinematics (Fig. 6A; Allen 1970b; Rubin and Hunter 1982). In 135 cases of dune climb, where trains of migrating dunes must climb over the accumulations of 136 downwind dunes, set boundaries are expected to originate from a lower, outcrop-scale bounding 137 surface and rise at some measurable angle. In cases where sets are filling a pre-existing 138 topographic low, the architecture is defined by set boundaries that originate at an upper, outcrop- 
139 scale bounding surface and descend, ultimately downlapping onto a lower, outcrop-scale

140 bounding surface that hosts the antecedent topographic low. Finally, in cases where variable

141 depth of trough scour creates space that is subsequently filled by smaller dunes in the train, sets

142 boundaries persist for limited distances before being cut out by other set boundaries rather than

143 by outcrop-scale bounding surfaces.

144 The architecture of set boundaries is not the only data type used here to reconstruct the

145 filling history. Distributions on set thickness also contain information as to how the stratification

146 formed (Paola and Borgman 1991; Bridge and Best 1997; Jerolmack and Mohrig, 2005). In

147 particular, distributions of cross-strata produced by the scour-and-fill process (Fig. 6A) record an

148 asymptotically high value for the coefficient of variation of bed thicknesses, while sets produced

149 during net bed aggradation (climbing and downlapping cases in Fig. 6A) have distinctly smaller

150 values for coefficient of variation associated with them. Here we have combined set architecture

151 with set statistics to increase our confidence in the reconstructed processes that produced the

152 observed stratigraphy.

153

154

METHODS

155

Field Work

Three outcrops in and near Page, Arizona, were selected based upon their accessibility

157 and orientation relative to the paleo-transport direction determined from a measured distribution

158 of cross-strata dip-directions (Fig. 7). The Ferry Swale outcrop was split into two sections; one

159 segment oriented perpendicular to the general dune migration direction and the other oblique to

160 the dune migration direction. The Manson Mesa and Golf Course sections were each oriented

161 roughly parallel to the transport direction. Cross-strata set boundaries and outcrop-scale 
162 bounding surfaces were surveyed using a total station at each outcrop location. A GPS point was

163 taken at each base station location so that all surveyed points could be converted to UTM

164 coordinates. Each outcrop-scale erosional surface was then correlated with vertical sections from

165 Havholm (1991). In addition to mapping surfaces, 90 measurements of foreset dip direction were

166 taken using a Brunton compass and averaged with the Circular Statistics Toolbox in MATLAB

167 (Berens 2012). Thicknesses of 161 cycles of wind-ripple and stacked grainflow strata were

168 collected from cross-strata. All of these measurements were collected from the basal Page (PB),

169 lower Page (PL), and middle middle Page (PMm) intervals of the Page Sandstone (Fig. 1). For

170 simplicity, we will refer to the middle middle Page as the middle Page. These divisions make up

171 the strata bounded by the underlying J-2 and overlying S-rm surfaces (Fig. 1B). The upper Page,

172 unit PUI of Figure 1, is composed of sets of compound-dune cross-strata that are distinctively

173 different from those of the underlying units and are not part of this study.

\section{Data Processing}

Combining field maps, with GPS datums and annotated total-station points, a digital GIS

176 project including all of the outcrop locations was constructed. Continuous surfaces were

177 interpolated from point data defining each outcrop-scale bounding surface and cross-strata set

178 boundary using kreiging method that completely preserves the XYZ input data. The spatial

179 resolution for resulting digital elevation models (DEMs) at Manson Mesa, the Golf Course, and 180 Ferry Swale is $0.55 \mathrm{~m}, 0.65 \mathrm{~m}$, and $2 \mathrm{~m}$.

Using the GIS, vertical stratigraphic sections were constructed at $20 \mathrm{~m}$ intervals across 182 each outcrop (Figs. 8- 9 and S1-S3). The 3-D mapping data allowed surfaces within each cross183 section to be accurately correlated. Measurements of set thickness and outcrop-scale bounding- 
184 surface relief were made from the generated cross-sections. Set geometry and its relationship to

185 the nearest bounding surface was also categorized from the cross-sections (Fig. 6A).

Swanson et al. (this issue) numerically model surface topography, dune migration, dune interactions, and cross-strata accumulation by coupling bed topography, bed shear stress, and sediment transport. Using this model, several outcrop-scale bounding surfaces and stratigraphic packages have been re-created in a 2-D panel. Observations of this synthetic stratigraphy are 191 compared to outcrop interpretations (Fig. 10; model parameters in Table S1.) To create the 192 synthetic Page stratigraphy, a dune field and its accumulations are developed for a set period of 193 time during which an initial rough surface develops into small, early-phase dunes, which develop 194 into larger, more mature dunes. Following that time, a relatively flat outcrop-scale bounding 195 surface is formed through the stratigraphy that has developed. Then, another dune field and its 196 accumulations develop on top of this outcrop-scale bounding surface. Four episodes of aeolian 197 accumulation are modeled in this scenario, creating four outcrop-scale packages bound by three 198 outcrop-scale bounding surfaces (Fig. 10). The synthetic stratigraphy is color-coded by age 199 relative to each accumulation episode.

\section{RESULTS}

At the three outcrops (Figs. 8-9 and S1-S3) the Page Sandstone is composed of packages

204 of aeolian cross-strata partitioned by the formation-scale surfaces of Havholm et al. (1993).

205 Within the studied interval spanning from the J-2 to the S-rm surfaces (Fig. 1), the Page is

206 nowhere thicker than $60 \mathrm{~m}$ and is largely composed of meter-scale beds of cross-strata in the 
207 lower and middle Page (Fig. 4A), with local preservation of thinner sets in the basal Page (Figs.

208 5A and 11A-D). In addition to the formation-scale surfaces that define the informal Page units,

209 Havholm et al. (1993) identified less-continuous surfaces that are typically truncated laterally.

210 For this study, the term “outcrop-scale bounding surface” refers to both the formation-scale and

211 less-continuous super surfaces identified by Havholm et al. (1993).

\section{Outcrop-Scale Bounding Surfaces}

Figures 8-9 and S1-S3 present the structure of the outcrop-scale bounding surfaces

214 surveyed at the three outcrop locations (Fig. 2). The J-2 surface is characterized by wedge-

215 shaped fractures into the underlying Navajo Formation, pebble-sized, diagenetic chert nodules

216 replacing evaporites within the uppermost Navajo strata, and up to $10 \mathrm{~m}$ of local erosional relief

217 (e.g., Ferry Swale; Fig. S1). The outcrop-scale bounding surfaces within the lower and middle

218 Page also preserve erosional relief that varies between a minimum of $1.2 \mathrm{~m}$ to as much as $13.5 \mathrm{~m}$

219 (Fig. 12A). On both walls of the Ferry Swale outcrop (Figs. 8-9), this relief has a scalloped

220 geometry. Horizontal distances from the adjacent high points on either side of a scallop were

221 measured on the western, perpendicular-to-transport wall (Fig. 8). The widths of sets filling these

222 scallops were measured on the same wall as the horizontal distance between pinchouts. Scallop

223 widths $(n=23)$ have a mean value of $72 \mathrm{~m}$ and a standard deviation of $34 \mathrm{~m}$. Sets filling these

224 scallops $(\mathrm{n}=33)$ have a similar mean width of $64 \mathrm{~m}$ and a greater standard deviation of $81 \mathrm{~m}$.

225 Outcrop-scale bounding surfaces are commonly associated with two unique deposit

226 types. Wavy-laminated sandstones with variable thicknesses ranging up to $0.4 \mathrm{~m}$ occur

227 discontinuously along outcrop-scale bounding surfaces in the lower and middle Page (Fig. 2A-

228 D). In the basal Page, the wavy laminated sandstones were identified both overlying the J-2

229 surface and in between aeolian cross-sets, and these strata are generally thicker and more 
230 continuous than in the higher Page units. As a whole, the red, wavy-laminated strata have been

231 interpreted as sabkha deposits that formed along surfaces deflated to the near-surface water table

232 (Havholm et al. 1993; Havholm and Kocurek 1994). The second deposit type primarily

233 associated with outcrop-scale bounding surfaces are prominent, wedge-shaped fracture fills. In

234 exposures that provide cross-sectional views, the fractures cross-cut sets of cross-stratified

235 sandstone (Fig. 3A-C). These fractures narrow downward, although not always in a linear

236 fashion. In plan-view, the fracture fills take a more polygonal shape (Fig. 3A). Sandstone fill

237 within the fractures is vertically-laminated or structureless (Fig. 3B-C). The tops of the wedges

238 terminate against outcrop-scale bounding surfaces. These sandstone wedges have been

239 interpreted as sand-filled, salt-cemented thermal contraction polygonal fractures (Kocurek and

240 Hunter 1986).

\section{Cross-Set Architecture}

The outcrop-scale bounding surfaces truncate and bound packages of cross-stratified

243 beds, referred to hereafter as "outcrop-scale packages.” Within these packages, individual sets of

244 cross-strata are defined by upper and lower set boundaries that are less continuous than the

245 outcrop-scale surfaces. The architecture of outcrop-scale packages varies from the basal to 246 middle Page.

247 Basal Page Architecture.---The thin sets of cross-stratified sandstone (Fig. 5A-B) are 248 relatively uncommon and limited to the basal Page at the outcrops studied. Set thicknesses range 249 from 0.03 to $0.45 \mathrm{~m}$ with a mean of $0.16 \mathrm{~m}$ and a standard deviation of $0.10 \mathrm{~m}$ (Fig. $5 \mathrm{C} ; \mathrm{n}=80$ ).

250 Individual grainflow deposits are well defined by their characteristic blade shape and are 251 separated by mm-thick grainfall deposits (Fig. 5B). Alternating grainflow and grainfall deposits 
252 define the cross-stratification in these sets. The mean grainflow deposit thickness is $18 \mathrm{~mm}$ with 253 a standard deviation of $9 \mathrm{~mm}$ (Fig. 5D; $\mathrm{n}=36)$.

In contrast to the lower and middle Page, the sets of the basal Page are stacked tens of 255 sets high to form packages several meters thick. This architecture occurs at Ferry Swale and 256 north of the Golf Course outcrop (Fig. 11A-D and 13). At the Ferry Swale outcrop, these thin 257 sets are located filling a local J-2 depression (Fig. S1 shows full J-2 topography at Ferry Swale). 258 North of the Golf Course outcrop, basal Page sets probably also fill a depression on the J-2 259 surface, but the contact with the Navajo is not exposed. At both locations, these packages of 260 stacked, thin sets are laterally scoured and filled by thicker sets of the lower Page (Fig. 11A-D 261 and 13).

262 The stacked, thin sets of the basal Page are the focus of our comparison between the basal 263 Page and the lower and middle Page. However, parts of the basal Page also consist of alternating 264 sabkha and cross-sets, as reported by Havholm et al. (1993) but not analyzed here.

265 Lower and Middle Page Architecture.---The predominant facies composing the lower 266 and middle Page at all three sites (Fig. 7) are thick sets of cross-stratified sandstones (Fig. 4A) 267 composed of foresets consisting of stacked grainflow strata separated by intervals of wind-ripple 268 laminae (Fig. 4B). Where grainflow cross-strata do not extend to the base of the set, these yield 269 downward to low-angle wind-ripple strata that form toesets (Fig. 4C). Individual grainflow 270 deposits cannot be distinguished, but rather form amalgamations of multiple grainflow deposits.

271 From 461 measurements made using the cross-sections (Figs. 8-9 and S1-S3), these sets of cross272 strata are on average $2.3 \mathrm{~m}$ thick, and occasionally exceed $10 \mathrm{~m}$ (Fig. 4D). The standard 273 deviation of set thicknesses is $2.1 \mathrm{~m}$. The thickness of individual sets is laterally variable at the 274 outcrop scale (Fig. 8-9), and sets are typically truncated by adjacent sets of cross-strata, limiting 
275 lateral continuity (Fig. 14A-B). The thicknesses of grainflow deposit packages were measured

276 from several sets of these cross-strata (e.g., Fig. 4B), and range from 0.01 to $1.30 \mathrm{~m}$ with an

277 average value and standard deviation of $0.19 \mathrm{~m}$ (Fig. 5D). Ninety measurements of foreset dip

278 direction were taken from this facies and serve as a proxy measurement of paleo-transport

279 direction. The mean of these measurements is $143^{\circ}$.

280 The number of sets stacked between outcrop-scale surfaces at any vertical section of the

281 lower and middle Page ranges from 1 to 5 (Figs. 8-9 and S1-S3). There is not a strong correlation

282 between the number of stacked sets and the thickness of the associated outcrop-scale package

283 (Fig. 12B). There is, however, a near one-to-one correlation between the thickness of an outcrop-

284 scale package and the maximum amount of relief along the associated lower outcrop-scale

285 bounding surface (Fig. 12A).

286

Using the cross-sections created for each outcrop (Figs. 8-9 and S1-S3), each of the sets

287 of the lower and middle Page was placed into one of the architectural categories defined in

288 Figure 6A. The categories describe in-transport set architectures, so sets in the perpendicular-to-

289 transport wall of Ferry Swale are not addressed here. The oblique-to-transport wall of Ferry

290 Swale is assumed to exhibit these characteristics well enough that those sets are included in the

291 count. Discontinuous, truncated sets fitting the scour-and-fill architecture occur most frequently,

292 although all architectural categories are identified in outcrop (Fig. 6B).

Several observations of the numerical model are relevant for interpreting the Page strata

295 (Fig. 10). Firstly, the relief along the modeled outcrop-scale bounding surfaces develops coevally

296 via dune scouring with the development of the dune field during each phase of aeolian

297 sedimentation. Secondly, this relief is filled with the accumulations of the relatively late-phase 
298 dunes associated with the creation of the scour relief. Thirdly, except for antecedent topographic

299 lows sequestering accumulations beneath the depths of scours to follow, there is almost no

300 preservation of strata representing the early-phases of the dune fields (Fig. 10).

301

302

\section{DISCUSSION}

The thin sets of cross-strata of the basal Page are interpreted to represent significantly

305 smaller dunes than those that gave rise to the sets of the lower and middle Page. The thin (mean

$306=0.16 \mathrm{~m}, \mathrm{n}=80$ ) sets of the basal Page are characterized by thin grainflow strata (Fig. 5D; mean

$307=17.6 \mathrm{~mm}, \mathrm{n}=37$ ) separated by grainfall deposits (Fig. 5B). Although the relationship between

308 grainflow deposit thickness and dune height may be modified by factors, especially wind speed

309 (McDonald and Anderson 1995; Nickling et al. 2002; Nield et al. 2017; Cornwall et al. 2018),

310 these consistently thin grainflow strata are characteristic of small dunes. Moreover, the common

311 presence of grainfall deposits between grainflow strata indicates small dunes where grainfall

312 deposits of observable thickness extended to the base of the set (Hunter 1977; Kocurek and Dott

313 1981).

314 Several observations indicate the lower and middle Page sets are the deposits of much

315 larger dunes. Firstly, these sets on average are an order of magnitude thicker $($ mean $=2.3 \mathrm{~m}, \mathrm{n}=$

316 461) than those of the basal Page, and trough widths measure on average $64 \mathrm{~m}(\mathrm{n}=33)$.

317 Secondly, the absence of grainfall deposits in the lower and middle Page sets is suggestive of

318 larger dunes where significant grainfall seldom reaches basal lee faces (Hunter 1977; Kocurek

319 and Dott 1981). Thirdly, the sets of the lower and middle Page show alternating grainflow and

320 wind-ripple strata, as described in detail in Kocurek et al. (1991). This alternation of 
321 stratification types is commonly interpreted as seasonal cycles reflecting varying wind directions

322 (Hunter and Rubin 1983). Large dunes formed with an abundant sand supply are oriented to the

323 gross bedform-normal transport direction (Rubin and Hunter 1987), such that not all seasonal

324 winds are transverse to the long-term crestline orientation. In contrast, repetitive packaging

325 characteristic of multiple transporting wind directions are absent in the sets of the basal Page,

326 which are interpreted to represent dunes small enough to reorient their crests with seasonal

327 changes in the wind regime (e.g., bedform response time is shorter than wind direction cycles,

328 Rubin and Hunter 1987; Ewing et al., 2015).

329 Dune fields begin as collections of protodunes that interact during migration and grow

330 into larger dunes (e.g., Werner 1995; Ewing and Kocurek 2010a; Swanson et al. 2017).

331 Therefore, the relatively small dunes associated with the deposition of the basal Page sets are

332 interpreted to represent an earlier phase of dune-field development when compared to the dune

333 fields that produced the larger sets of the lower and middle Page. Significantly, there are no

334 preserved strata from a comparably early phase of dune-field development within the lower and

335 middle Page. This is consistent with the model results (Fig. 10).

Stratigraphic Architecture and Outcrop-Scale Bounding Surface Topography

Architecture Preserved Within Antecedent J-2 Topography.---The J-2 regional

338 surface represents regional erosion (Pipiringos and O’Sullivan 1978), and relief on this surface in

339 the Page area is therefore not interpreted to be a product of dune scour associated with the

340 migration of Page dunes. Rather, J-2 topography is interpreted as antecedent to the development

341 of the Page system. Depressions along this surface had a measurable effect upon the architecture

342 of the Page Sandstone by providing local accommodation space for sabkha deposits, packages of

343 wind-ripple strata (Kocurek et al. 1991; Havholm et al. 1993), and local shallow pond deposits 
344 (Swezey 1991). Antecedent depressions in the J-2 are also filled by stacks of thin cross-sets interpreted as representing small dunes of a juvenile dune field within the Page. These deposits aggraded here owing to local wind deceleration over the depression.

The J-2 antecedent relief also acted to prevent reworking of the early-phase strata by later, deep-scouring large dunes (Fig. 11A-D), as predicted by the numerical model (Fig. 10). Even so, packages of thin sets were partially scoured during reactivations of the Page dune fields and subsequently filled by thicker beds of cross-strata composed of grainflow and wind-ripple deposits. In the example at Ferry Swale, lateral scour of a section of basal Page (Fig. 11 C-D) is part of a large scoured depression that was subsequently filled by strata from at least two sides (Fig. 13). Near the Golf Course outcrop, several meters of stacked, thin sets of the basal Page are laterally truncated by a thick set of lower Page (Fig. 11 A-B). Although this section of basal Page was probably also formed within a J-2 depression, the J-2 surface is locally covered along adjacent outcrops of Navajo Sandstone. Aggradation of early phases of Page dune fields may have occurred beyond localized J-2 depressions but, ultimately, as dunes grew in size, these accumulations were likely completely cannibalized.

\section{Scour-and-Fill Architecture and Coeval Development of Outcrop-Scale Bounding}

Surface Relief.---Several lines of evidence support a scour-and-fill type architecture for the lower and middle Page. In the perpendicular-to-transport wall of the Ferry Swale outcrop (Fig. 8), the similarity in width of the topographic scallops and the sets of cross-strata that fill the scallops indicates that (1) the topographic scallops were created by dune migration, and (2) the sets filling the scallops were deposited by the dunes that created the scour. This scour-and-fill architecture is in sharp contrast to that of the antecedent $\mathrm{J}$-2 surface where the fill does not scale with the erosional relief. Because the outcrop-scale bounding surfaces represent a lateral 
367 continuum of distinct scallops (e.g., Fig. 8), these surfaces can be viewed as compound erosional

368 surfaces. Although seen in outcrop as continuous surfaces with erosional relief, the outcrop-scale

369 surfaces are interpreted to have formed with the passage of multiple dunes with varying scour

370 depth. Moreover, consistent with the numerical model (Fig. 10), the ultimate relief on the surface

371 would reflect the passage of the largest dunes with the deepest scours. This interpretation is

372 consistent with the local truncation of sections of basal Page by the passage of large scours (Figs.

373 11, 13), and the lateral truncation of outcrop-scale packages by subsequent scour (Fig. 9). At the

374 regional scale, Havholm et al. (1993) show the scour of the entire upper middle Page (PMu)

375 along the regional traverse (Fig. 1B), and deep scours have been described elsewhere for the

376 Page (Blakey 1988). For the latter examples, scour associated with the passage of trains of large

377 dunes is not unreasonable, but other deflationary processes cannot be discounted.

378

Figure 12B compares the number of sets within an outcrop-scale package at a vertical

379 section to the thickness of the outcrop-scale package at that same vertical section. There is not a

380 significant correlation between the two measurements. A plot comparing the maximum relief

381 across an outcrop-scale bounding surface to the thickness of the outcrop-scale package above

382 that surface, however, shows a strong one-to-one relationship (Fig. 12A). The two plots

383 demonstrate that although topographic depressions along outcrop-scale bounding surfaces do aid

384 in the preservation of more of the rock record (i.e., a thicker outcrop-scale package), this thicker

385 section does not correlate with a greater number of sets within an outcrop-scale package.

386 Consistent with field observations, there is no selective preservation of more sets or of early-

387 phase strata within deeper scours. This observation is again in contrast with the J-2 surface,

388 where negative relief of the same scale houses accumulations of early-phase strata. 
As also evident from Figure 12B, most outcrop-scale packages consist of only one or two

390

391

392

393

394

395 sets of cross-strata. In the case of one set comprising the entire outcrop-scale package, the preserved record consists of the scoured trough and cross-strata fill of only the largest dune to migrate across the area. As predicted by the numerical model (Fig. 10), additional sets within an outcrop-scale package record the scour and fill of successive dunes that did not remove underlying sets. Consistent with the model, the dominant architecture of Page sets of cross-strata is one that represents scour-and-fill (Fig. 6).

Set thickness and set architecture within a preserved accumulation (i.e., an outcrop-scale package) are a function of climb angle and variability in scour depth (Fig. 12C; Paola and Borgman 1991). The dominance of scour-and-fill set architecture throughout the studied interval of the Page Sandstone suggests very low climb angles such that the deepest trough-scouring depths are the predominant control on set thickness (Fig. 12C; Paola and Borgman 1991; Bridge and Best 1997; Swanson et al. companion). This interpretation can be tested using relationships first established in Paola and Borgman (1991) and further generalized by Bridge and Best (1997) and Leclair et al. (1997). Mean set thickness, $s_{m}$, is a function of climb angle $(\delta)$, dune spacing $(l)$, mean dune height $\left(h_{m}\right)$, and the standard deviation of dune heights $\left(h_{s d^{2}}\right)$ :

$$
S_{m}=l \tan (\delta)+0.8225\left(h_{s d}^{2} / h_{m}\right)
$$

In Equation 1, $l \tan (\delta)$ describes the portion of mean set thickness due to climb (Allen, 1970b; Rubin and Hunter, 1982) and its associated net bed aggradation. The right-hand term, $0.8225\left(h_{s d}^{2} / h_{m}\right)$, describes the portion of mean set thickness produced by variability in dune size and thus, variability in scour depth. In the case of zero aggradation $(\delta=0), s_{m}$ is only a function of variability in dune size:

$$
s_{m}=0.8225\left(h_{s d}^{2} / h_{m}\right) .
$$


412 Bridge and Best (1997) note that with a climb angle of zero and gamma-distributed bedform

413 heights, the standard deviation of set thicknesses $\left(\mathrm{s}_{\sigma}\right)$ is:

$$
S_{\sigma}=0.725\left(h_{s d}^{2} / h_{m}\right) \text {. }
$$

415 Equations 2 and 3 can both be re-arranged to solve for $h_{s d}{ }^{2} h_{m}$, yielding

$$
s_{m} / 0.8225=s_{\sigma} / 0.725
$$

418 for the case of no dune climb. Rearranging the terms in this equation yields a predicted value for 419 the coefficient of variation of set thicknesses in the end-member case of zero net bed 420 aggradation:

421

$$
S_{\sigma} / S_{m}=0.88
$$

422 Because we have connected the dominance of scour-and-fill style sedimentation with a lack of 423 significant aggradation using other arguments, the hypothesis is that Equation 5 should hold true 424 for the lower and middle Page Sandstone assuming Page trough elevations were gamma 425 distributed. It should be noted that Equation 5 is particularly useful in analyses of paleo-systems 426 because it only requires measurements of set thicknesses that can be directly acquired in the 427 field.

Using 461 measurements of thickness for sets of cross-strata preserved in the lower and 429 middle Page yield an $s_{m}=2.34 \mathrm{~m}$ and $s_{\sigma}=2.10 \mathrm{~m}$ (Fig. 4D). Their ratio is 0.90 , which is very 430 close to the predicted 0.88 value of Equation 5. Importantly, the measured value is slightly 431 greater than the predicted value. The inclusion of climb acts to reduce the value of the ratio until, 432 with significant climb, the ratio is equal to that for the distribution of formative dune heights 433 (Jerolmack and Mohrig 2005). This is consistent with the relatively long tail of the distribution, 434 also observed by Jerolmack and Mohrig (2005) (Fig. 4D). In contrast, the stacked sets of the 
435 basal Page have an $s_{m}=0.16 \mathrm{~m}$ and $s_{\sigma}=0.10 \mathrm{~m}$, yielding a coefficient of variation of 0.64 . This

436 value represents a higher aggradation rate and climb angle than is recorded in the lower and

437 middle Page, consistent with the shorter tail of the set thickness distribution (Fig. 9C; Jerolmack

438 and Mohrig 2005). This result from analysis of Page set thicknesses supports the argument for

439 construction of these basal Page sets via the filling of antecedent J-2 depressions, while scour-

440 and-fill dominated sets of the lower and middle Page are consistent with production under

441 conditions of no climb or net bed aggradation. Set geometries and set statistics yield

442 independent yet similar conclusions as to the mix of processes preserving cross-strata.

443

444

445

446

447

448

449

450

451

452

453 aggradation.

To demonstrate the universality of set thickness statistics in analyses of aeolian strata, the method was applied to set thickness measurements from the nearby Jurassic Entrada Sandstone, a type-example of an aggradational dune field with measurable positive climb angles (CarrCrabaugh and Kocurek 1998; Kocurek and Day 2017). Thicknesses of 37 Entrada sets were taken from two vertical sections from Figure 2 of Kocurek and Day (2017), one characterized by downlapping sets filling a depression, and the other by climbing sets. For the Entrada, $s_{m}=2.10$ meters, $s_{\sigma}=0.96 \mathrm{~m}$, and their ratio is 0.46 . This ratio value suggests sufficient aggradation such that the coefficient of variation for set thickness more closely reflects the coefficient of variation for the distribution of dune heights (Jerolmack and Mohrig 2005) rather than Equation 5. Indeed, Kocurek and Day (2017) interpret the Entrada strata as the product of allogenically-forced bed Role of Autogenic vs. Allogenic Controls on the Page Preserved Record Prior work has addressed the difference in accumulation vs. preservation in the Page

456 Sandstone at the regional scale by tracing formation-scale packages of sets of cross-strata and 457 their bounding surfaces (Havholm and Kocurek 1994; Blakey et al. 1996). Our new work focuses 
upon the architecture of the sets within these formation-scale packages. Our measurements and interpretations are entirely consistent with those of the prior work, and additional observations informed by the results of Swanson et al. (this issue) allow for the reframing of the Page as a

461 record of competing autogenic and allogenic signals, as is commonly done in fluvial and marine 462 clastic depositional systems (Hajek and Straub 2017).

Autogenic variability in dune scour depth creates the scour-and-fill architecture observed 464 throughout most of the Page Sandstone, identified here by set geometry and high variability in 465 set thickness. There is no indication that any allogenic forcing beyond those allowing for 466 transport have affected the architecture of the accumulations, indicating the water table was well 467 below any point along the surface. This interpretation is consistent with previous work (Havholm 468 and Kocurek 1994; Blakey et al., 1996), which interpreted Page dune constructional periods as 469 occurring during low stands when the continental water table fell and sediment supply and 470 availability increased. This new study argues that the periods of dune construction were 471 characterized by scour of the substrate by migrating dunes with an accumulation that represents 472 fill of these scours. Because the scours cannibalize underlying sediment, earlier stages of dune473 field construction were reworked, as predicted by the numerical model (Fig. 10). Autogenic processes of dune scour-and-fill alone, however, will not result in the 475 preservation of stacked multiple dune constructional periods that represent the Page Sandstone. 476 Indeed, without any additional forcing, the Page dune fields would be represented by an 477 erosional surface and strata preserved just within depressions along the J-2 surface. In agreement 478 with previous work (Havholm and Kocurek 1994; Blakey et al. 1996), preservation of Page 479 accumulations is best accredited to allogenic forcing, which consisted of an episodic, but net 480 progressive rise of the continental water table as a function of sea level in the adjacent Carmel. 
481 The preserved accumulations capture those portions of the scour fill that were incorporated

482 within the rising water table. Field evidence argues that high stands of the Carmel sea were

483 characterized inland not only by a limit to deflation of the aeolian accumulations, but also a

484 diminished sand supply such that dune fields were replaced by extensive polygonally fractured

485 surfaces and sabkha deposition. Subsequent aeolian constructional periods during falling sea

486 level and low stands were characterized by an influx of additional sand but also by scour into the

487 surface, producing the compound erosional outcrop-scale surfaces. Scour was likely at least

488 locally limited by the evaporite-cemented, polygonally-fractured surface (Havholm and Kocurek

489 1994). The set architecture of the preserved accumulations argue that scour-and-fill processes

490 strongly dominated over dune climb.

491 The corollary to this interpretation is that antecedent topography and autogenically-

492 formed dune scour topography along outcrop-scale bounding surfaces can be distinguished from

493 one another. Relief autogenically formed from variability in scour depths typically cannibalizes

494 early-phase accumulations, and scour widths scale well with the widths of the filling sets. The

495 scour of the basal surface coeval with dune migration is consistent with the scour-and-fill

496 architecture of the cross-sets themselves, as well as with prior interpretations regarding the

497 formation of erosional outcrop-scale bounding surface relief (Havholm and Kocurek 1994).

498 Broadly speaking, the preservation any non-scour-and-fill type architecture represents an

499 allogenic forcing overcoming the autogenic, signal-shredding tendencies of the ancient Page

500 dune fields. This is consistent with much of the current theory regarding the recording of

501 environmental signals in stratigraphy (Jerolmack and Paola 2010; Paola et al. 2018), and framing

502 future observations of aeolian stratigraphy in this manner will be informative of ancient

503 environmental conditions on Earth and other planetary bodies with aeolian stratigraphic records, 
504

505

506

507

508

509

510

511

512

513

514

515

516

517

518

519

520

521

522

523

524

525

526

particularly Mars (e.g., Grotzinger et al. 2005; Milliken et al. 2014; Brothers et al. 2018; Banham et al. 2018; Day and Catling 2018; Anderson et al. 2018).

\section{CONCLUSIONS}

The Page Sandstone preserves a record of allogenic boundary conditions episodically overcoming an autogenic tendency of the dune field to shred its prior accumulations. Using field data and numerical modeling, the architecture of the Page Sandstone is characterized and linked

to autogenic and allogenic forcings. Antecedent depressions along the J-2 surface allowed for the accumulation of early dune field deposits, identifiable by thin sets of cross-strata characterized by thin grainflow strata separated by basal grainfall deposits. These depressions also acted to locally preserve this early-phase stratigraphy from later scour. In contrast, periods of dune accumulation represented by the lower and middle Page were characterized by a lack of antecedent topography, a water table well below the depositional surface, and significant variation in dune scour depth. The compound erosional outcrop-scale bounding surfaces and scour-and-fill architecture of the accumulations are consistent with the reworking of any early dune field strata and argue that dune climb was subordinate to scour-depth variation in creating the set architecture. Topography developed by dune scour may be differentiated from antecedent relief by having similar scales of scour and fill. Numerical modeling presented here and in the companion paper (Swanson et al. this issue) highlight the scour of strata formed during early stages of dune field construction by subsequent autogenic dune scour. In contrast to the dominance of autogenic processes in shaping the architecture of the dune accumulations, their preservation requires allogenic forcing, which was the episodic and net progressive rise of the water table high associated with Carmel transgressions. Without episodic high stands driving 
527 preservation, the Page dune fields would likely be represented an amalgamated erosional surface 528 and local preservation within J-2 depressions.

529 The methods used here to quantify the set architecture of the Page Sandstone are

530 universal, and can be applied to any other aeolian sandstone where there is interest in 531 understanding the formative environmental conditions of the associated ancient dune field. In 532 addition to other Earth outcrops, aeolian sandstones on Mars could be characterized by similar 533 methods using rover and remote sensing data.

\section{ACKNOWLEDGEMENTS}

The authors would like to thank Dan T.S.M. Aylward for his assistance in the field. John

537 Spence at the Glen Canyon Dam National Park Service and Jake Hunter at Lake Powell National 538 Golf Course were helpful in facilitating outcrop access. We also thank Joe Levy for the use of his 539 field equipment, and the David Mohrig Research Group and Shell Clastics Research Group for 540 discussions and feedback throughout the evolution of this project. This work was supported by 541 Shell International Exploration and Production Inc., the RioMar Industry Consortium, and the 542 University of Texas Jackson School of Geosciences.

\section{REFERENCES}

545 Allen, J.R.L., 1970a, The Avalanching of Granular Solids on Dune and Similar Slopes: The $546 \quad$ Journal of Geology, v. 78, p. 326-351.

547 Allen, J.R.L., 1970b, A Quantitative Model of Climbing Ripples and Their Cross-Laminated 548 Deposits: Sedimentology, v. 14, p. 5-26. 
Anderson, R.B., Edgar, L.A., Rubin, D.M., Lewis, K.W., and Newman, C., 2018, Complex bedding geometry in the upper portion of Aeolis Mons, Gale Crater, Mars: Icarus, v. 314, p. 246-264.

Baitis, E., Kocurek, G., Smith, V., Mohrig, D., Ewing, R.C., and Peyret, A.-P. B., 2014, Definition and origin of the dune-field pattern at White Sands, New Mexico: Aeolian Research, v. 15, p. 269-287.

Banham, S.G., Gupta, S., Rubin, D.M., Watkins, J.A., Sumner, D.Y., Edgett, K.S., Grotzinger, J.P., Lewis, K.W., Edgar, L.A., Stack-Morgan, K.M., Barnes, R., Bell III, J.F., Day, M.D., Ewing, R.C., Lapotre, M.G.A., Stein, N.T., Rivera-Hernandez, F., and Vasavada, A.R., 2018, Ancient Martian aeolian processes and palaeomorphology reconstructed from the Stimson formation on the lower slope of Aeolis Mons, Gale crater, Mars: Sedimentology, v. 65, p. 993-1042.

Berens, P., 2009, CircStat: A MATLAB Toolbox for Circular Statistics: Journal of Statistical Software, v. 31, p. 1-21.

Blakey, R.C., 1988, Superscoops: their significance as elements of eolian architecture: Geology, v. 16, p. 483-487.

Blakey, R.C., Peterson, F., Caputo, M.V., Geesaman, R.C., and Voorhees, B.J., 1983, Paleogeography of Middle Jurassic Continental, Shoreline, and Shallow Marine Sedimentation, Southern Utah. in Dunne, G. C., McDougall, K. A., editors, Mesozoic Paleogeography of the Western United States - II, v. 71, p. 77-100. 
Blakey, R.C., Peterson, F., and Kocurek, G., 1988, Synthesis of late Paleozoic and Mesozoic eolian deposits of the Western Interior of the United States: Sedimentary Geology, v. 56, p. 3-125.

Blakey, R.C., and Parnell, R.A., 1995, Middle Jurassic magmatism: The volcanic record in the eolian Page Sandstone and related Carmel Formation, Colorado Plateau: Geological Society of America Special Papers, v. 299, p. 393-412.

Blakey, R.C., Havholm, K.G., and Jones, L.S., 1996, Stratigraphic analysis of eolian interactions with marine and fluvial deposits, Middle Jurassic Page Sandstone and Carmel Formation, Colorado Plateau, USA: Journal of Sedimentary Research, v. 66, p. 324-342.

Bridge, J., and Best, J., 1997, Preservation of planar laminae due to migration of low-relief bed waves over aggrading upper-stage plane beds: comparison of experimental data with theory: Sedimentology, v. 44, p. 253-262.

Brothers, S.C., Kocurek, G., Brothers, T.C., and Buynevich, I.V., 2017, Stratigraphic architecture resulting from dune interactions: White Sands Dune Field, New Mexico: Sedimentology, v. 64, p. 686-713.

Brothers, S.C., Kocurek, G., and Holt, J.W., 2018, Sequence architecture of the cavi unit, Chasma Boreale, Mars: Icarus, v. 308, p. 42-60.

Capps, D.M., 1990, Presence and significance of regional bounding surfaces and genetic sequences in an eolian sandstone: Page Sandstone (Jurassic), south-central Utah: Unpublished Ph.D. Dissertation, Northern Arizona University, Flagstaff.

Cornwall, C., Jackson, D.W.T., Bourke, M.C., and Cooper, J.A. G., 2018, Morphometric analysis of slipface processes of an aeolian dune: Implications for grain-flow dynamics: Sedimentology, in press. 
592 Crabaugh, M., and Kocurek, G., 1993, Entrada Sandstone: an example of a wet aeolian system:

593 Geological Society, London, Special Publications, v. 72, p. 103-126

594 Day, M.D., and Catling, D.C., 2018, Dune casts preserved by partial burial: The first

595 identification of ghost dune pits on Mars: Journal of Geophysical Research: Planets, v. $596 \quad$ 123, p. 1431-1448.

597 Day, M.D., and Kocurek, G., 2017, Aeolian dune interactions preserved in the ancient rock 598 record: Sedimentary Geology, v. 358, p. 187-196.

599 Day, M.D., and Kocurek, G., 2018, Pattern similarity across planetary dune fields: Geology, in $600 \quad$ press.

601 Dickinson, W.R., Stair, K.N., Gehrels, G.E., Peters, L., Kowallis, B.J., Blakey, R.C., Amar, J.R., 602 and Greenhalgh, B.W., 2010, U-Pb and 40Ar/39Ar Ages for a Tephra Lens in the Middle 603 604 605 606 607 608 609 610 Jurassic Page Sandstone: First Direct Isotopic Dating of a Mesozoic Eolianite on the Colorado Plateau: The Journal of Geology, v. 118, p. 215-221.

Eastwood, E.N., Kocurek, G., Mohrig, D., and Swanson, T., 2012, Methodology for reconstructing wind direction, wind speed and duration of wind events from aeolian cross-strata: Journal of Geophysical Research: Earth Surface, v. 117, F03035.

Ewing, R.C., and Kocurek, G., 2010a, Aeolian dune-field pattern boundary conditions: Geomorphology, v. 114, p. 175-187.

Ewing, R.C., and Kocurek, G., 2010b, Aeolian dune interactions and dune-field pattern formation: White Sands Dune Field, New Mexico: Sedimentology, v. 57, p. 1199-1219.

Ewing, R.C., McDonald, G.D., and Hayes, A.G., 2015, Multi-spatial analysis of aeolian dune613 field patterns: Geomorphology, v. 240, p. 44-53. 
614 Galloway, W.E., 1989, Genetic stratigraphic sequences in basin analysis I. Architecture and

615

616

617

618

619

620

621

622

623

624

625

626

627

628

629

630

631

632

633

634

635 genesis of flooding-surface bounded depositional units: The American Association of Petroleum Geologists Bulletin, v. 73, p. 125-142.

Gao, X., Narteau, C., and Rozier, O., 2015a, Development and steady states of transverse dunes: A numerical analysis of dune pattern coarsening and giant dunes. Journal of Geophysical Research: Earth Surface, v. 120, 2015JF003549.

Gao, X., Narteau, C., Rozier, O., and du Pont, S.C., 2015b, Phase diagrams of dune shape and orientation depending on sand availability: Scientific Reports, v. 5, 14677.

Grotzinger, J.P., Arvidson, R.E., Bell III, J.F., Calvin, W., Clark, B.C., Fike, D.A., Golombek, M., Greeley, R., Haldemann, A., Herkenhoff, K.E., Jolliff, B.L., Knoll, A.H., Malin, M., McLennan, S.M., Parker, T., Soderblom, L., Sohl-Dickstein, J.N., Squyres, S.W., Tosca, N.J., and Watters, W.A., 2005, Stratigraphy and sedimentology of a dry to wet eolian depositional system, Burns formation, Meridiani Planum, Mars: Earth and Planetary Science Letters, v. 240, p. 11-72.

Hajek, E.A., and Straub, K.M., 2017, Autogenic sedimentation in clastic stratigraphy: Annual Review of Earth and Planetary Sciences, v. 45, p. 681-709.

Havholm, K.G., 1991, Eolian event stratigraphy: theory, and application to the middle Jurassic Page Sandstone, Colorado Plateau, U.S.A.: Unpublished Ph.D. Dissertation, University of Texas at Austin, Austin, 181 p.

Havholm, K.G., Blakey, R.C., Capps, M., Jones, L.S., King, D.D., and Kocurek, G., 1993. Aeolian genetic stratigraphy: an example from the Middle Jurassic Page sandstone, Colorado Plateau: Int. Ass. Sediment. Special Publication, v. 16, p. 87-107. 
Havholm, K.G., and Kocurek, G., 1994. Factors controlling aeolian sequence stratigraphy: clues from super bounding surface features in the Middle Jurassic Page Sandstone: Sedimentology, v. 41, p. 913-934.

Hunter, R.E., 1977, Basic types of stratification in small eolian dunes: Sedimentology, v. 24(3), p. 361-387.

Hunter, R.E., and Rubin, D.M., 1983, Interpreting Cyclic Crossbedding, with an Example from the Navajo Sandstone: Eolian Sediments and Processes, Eds. Brookfield, M. E. and Ahlbrandt, T. S., v. 83, p. 429-454.

Jerolmack, D.J., and Mohrig, D., 2005, Frozen dynamics of migrating bedforms: Geology, v. 33, p. $57-60$.

Jerolmack, D.J., and Paola, C., 2010, Shredding of environmental signals by sediment transport: Geophysical Research Letters, v. 37, L19401.

Jones, L.S., 1990, Stratigraphy and depositional history of the Page Sandstone and correlative units of the Carmel Formation: Unpublished Master’s Thesis, Northern Arizona University, Flagstaff.

Jones, L.S., and Blakey, R.C., 1993, Erosional Remnants and Adjacent Unconformities Along an Eolian-Marine Boundary of the Page Sandstone and Carmel Formation, Middle Jurassic, South-Central Utah: Journal of Sedimentary Research, v. 63, p. 852-859.

King, D.D., 1992, Stratigraphic analysis of the landward margin of the Middle Jurassic Page Sandstone: Unpublished Master’s Thesis, Northern Arizona University, Flagstaff.

Kocurek, G., 1981, Significance of interdune deposits and bounding surfaces in aeolian dune sands: Sedimentology, v. 28, p. 753-780. 
Kocurek, G., 1988, First-order and super bounding surfaces in eolian sequences-Bounding surfaces revisited: Sedimentary Geology, v. 56, p. 193-206.

Kocurek, G., and Day, M.D., 2017, What is preserved in the aeolian rock record? A Jurassic Entrada Sandstone case study at the Utah-Arizona border: Sedimentology, v. 65, p. 13071321.

Kocurek, G., and Dott Jr, R.H., 1981, Distinctions and uses of stratification types in the interpretation of eolian sand: Journal of Sedimentary Research, v. 51, p. 579-595.

Kocurek, G., and Dott Jr, R.H., 1983, Jurassic Paleogeography and Paleoclimate of the Central and Southern Rocky Mountains Region: in Reynolds, M. W., Dolly, E. D. (editors), Mesozoic Paleogeography of the West-Central United States, Rocky Mt. Paleogeogr. Symp., v. 2, Rocky Mt. Sect. SEPM, Denver, p. 101-116.

Kocurek, G., and Havholm, K.G., 1993, Eolian Sequence Stratigraphy-A Conceptual Framework: Chapter 16: Recent Developments in Siliciclastic Sequence Stratigraphy. AAPG Memoirs, v. 58, p. 393-409.

Kocurek, G., and Hunter, R.E., 1986, Origin of polygonal fractures in sand, uppermost Navajo and Page sandstones, Page, Arizona: Journal of Sedimentary Research, v. 56, p. 895-904.

Kocurek, G., Knight, J., and Havholm, K., 1991, Outcrop and semi-regional three-dimensional architecture and reconstruction of a portion of the eolian Page Sandstone (Jurassic): SEPM Concepts in Sedimentology and Paleontology, Miall, A.D. and Tyler, N., editors, v. 3, p. 25-43.

Kocurek, G., Ewing, R.C., and Mohrig, D., 2010, How do bedform patterns arise? New views on the role of bedform interactions within a set of boundary conditions: Earth Surface Processes and Landforms, v. 35, p. 51-63. 
681 Kocurek, G., Robinson, N.I., and Sharp Jr., J.M., 2001, The response of the water table in coastal

682

683

684

685

686

687

688

689

690

691

692

693

694

695

696

697

698

699

700

701

702

703

aeolian systems to changes in sea level: Sedimentary Geology, v. 139, p. 1-13.

Leclair, S.F., Bridge, J.S., and Wang, F., 1997, Preservation of cross-strata due to migration of subaqueous dunes over aggrading and non-aggrading beds: comparison of experimental data with theory: Geoscience Canada, v. 24, p. 55-66.McDonald, R. P., and Anderson, R. S., 1995, Experimental verification of aeolian saltation and lee side deposition models: Sedimentology, v. 42, p. 39-56.

Milliken, R.E., Ewing, R.C., Fischer, W.W., and Hurowitz, J., 2014, Wind-blown sandstones cemented by sulfate and clay minerals in Gale Crater, Mars: Geophysical Research Letters, v. 41, p. 1149-1154.

Nickling, W.G., McKenna Neuman, C., and Lancaster, N., 2002, Grainfall processes in the lee of transverse dunes, Silver Peak, Nevada: Sedimentology, v. 49, p. 191-209.

Nield, J.M., Wiggs, G.F.S., Baddock, M.C., and Hipondoka, M.H.T., 2017, Coupling leeside grainfall to avalanche characteristics in aeolian dune dynamics: Geology, v. 45, p. 271274.

Paola, C., and Borgman, L., 1991, Reconstructing random topography from preserved stratification: Sedimentology, v. 38, p. 553-565.

Paola, C., Ganti, V., Mohrig, D., Runkel, A.C., and Straub, K.M., 2018, Time not our time: Physical controls on the preservation and measurement of geologic time: Annual Review of Earth and Planetary Sciences, v. 46, p. 409-438.

Pedersen, A., Kocurek, G., Mohrig, D., and Smith, V., 2015, Dune deformation in a multidirectional wind regime: White Sands Dune Field, New Mexico: Earth Surface Processes and Landforms, v. 40, p. 925-941. 
Peterson, F., 1994, Sand Dunes, Sabkhas, Streams, and Shallow Seas: Jurassic Paleogeography in the Southern Part of the Western Interior Basin: in Caputo, M. V., Peterson, N. A., and Franczyk, K. J., editors, Mesozoic systems of the Rocky Mountain region, USA, Rocky Mt. Sect., SEPM, p. 233-272.

Ping, L., Narteau, C., Dong, Z., Zhang, Z., and Pont, S.C. du., 2014, Emergence of oblique dunes in a landscape-scale experiment. Nature Geoscience, v. 7, p. 99.

Pipiringos, G.N., and O’Sullivan, R.B., 1978, Principal unconformities in Triassic and Jurassic rocks, western interior United States; a preliminary survey: USGS Numbered Series No. 1035-A, 35 p.

Pont, S.C. du, Narteau, C., and Gao, X., 2014, Two modes for dune orientation: Geology, 42, p. 743-746.

Riggs, N.R., and Blakey, R.C., 1993, Early and Middle Jurassic Paleogeography and Volcanology of Arizona and Adjacent Areas: in Dunne, G. C., McDougall, K. A., editors, Mesozoic Paleogeography of the Western United States - II, v. 71, p. 347-373.

Rodríguez-López, J.P., Clemmensen, L.B., Lancaster, N., Mountney, N.P., and Veiga, G.D., 2014, Archean to Recent aeolian sand systems and their sedimentary record: Current understanding and future prospects: Sedimentology, v. 61, p. 1487-1534.

Rubin, D.M., 1987, Cross-bedding, bedforms, and paleocurrents: Society of Economic Paleontologists and Mineralogists, Tulsa, 187 p.

Rubin, D.M., and Hunter, R.E., 1982, Bedform climbing in theory and nature: Sedimentology, v. 29, p. 121-138. 
725 Rubin, D.M., and Hunter, R.E., 1987, Bedform alignment in directionally varying flows: Science, v. 237, p. 276-278.

727 Swanson, T., Mohrig, D., and Kocurek, G., 2016, Aeolian dune sediment flux variability over an annual cycle of wind: Sedimentology, v. 63, p. 1753-1764.

729 Swanson, T., Mohrig, D., Kocurek, G., Cardenas, B.T., and Wolinsky, M.A., THIS ISSUE, Preservation of autogenic processes and allogenic forcings within set-scale aeolian architecture I: numerical experiments: Journal of Sedimentary Research.

732 Swanson, T., Mohrig, D., Kocurek, G., and Liang, M., 2017, A Surface Model for Aeolian Dune 733 Topography: Mathematical Geosciences, v. 49, p. 635-655.

734 Sweet, M.L., and Kocurek, G., 1990, An empirical model of aeolian dune lee-face airflow: Sedimentology, v. 37, 1023-1038.

Swezey, C., 1991, Description and interpretation of the Jurassic J-2 unconformity of the Western Interior (U.S.A.): Unpublished MS Thesis, University of Texas at Austin, Austin, 144 p.

Taggart, S., Hampson, G.J., and Jackson, M.D., 2010, High-resolution stratigraphic architecture and lithological heterogeneity within marginal aeolian reservoir analogues: Sedimentology, v. 57, p. 1246-1279. 23, p. 1107-1110. 


\section{FIGURES}

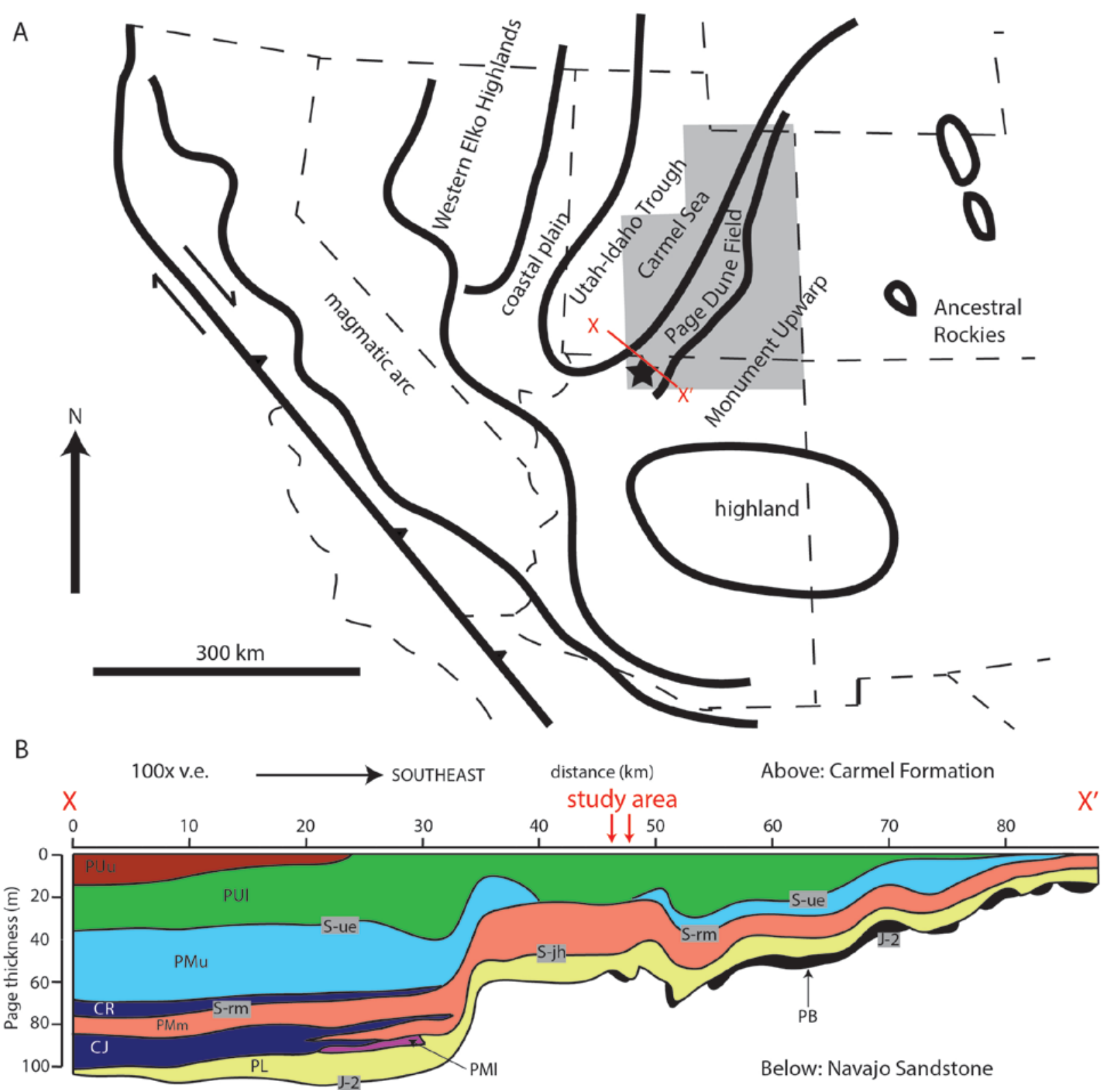

Figure $1(18.2 \mathrm{~cm}$ x $17.7 \mathrm{~cm})$ - A: Paleogeography of the Western Interior during the Middle Jurassic. The Page dune fields extended along the Carmel coastline, and were not present or were not preserved eastward over the Monument Upwarp. The gray box indicates the extent of Page and Carmel mapped by Havholm et al. (1993), Jones and Blakey (1993) and Blakey et al. (1996). The black star marks the location of Page, Arizona, and the outcrops discussed in this study. The 
red line X-X' shows the location of the cross-section in panel B. Modified after Havholm et al. (1993) and Peterson (1994). B: NW-SE cross-section X-X' showing the architecture of the Page Sandstone over more than 80 km. Figure is generalized after (Havholm et al., 1993, their Fig. 4D), but the cross-section has been hung from the Page/Carmel contact instead of the S-rm surface as in Havholm et al. (1993). Red arrows define the area of this study along the formationscale cross-section. Overall, the cross-section shows the thinning of the Carmel/Page stratigraphic unit from the basin onto the flanks of the Monument Upwarp. Major formationscale bounding surfaces separating informal units used by Havholm et al. (1993) are given. Page basal deposits (PB) and lower Page (PL) lie on the J-2 surface and are upward bounded by the Sjh surface. Westward the S-jh surface is overlain by a lower tongue of the Judd Hollow Member (CJ) of the Carmel Formation. Combined, the basal deposits and lower Page are the Harris Wash Member of Blakey et al. (1996). The middle Page (PM) or the Thousand Pockets Member of Blakey et al. (1996) is divided into lower (PMl), middle (PMm) and upper (PMu). PMl is bounded by a surface that is overlain by a higher, lesser tongue of the Judd Hollow. PMm is bounded by the S-rm surface, which is overlain westward by an upper tongue of the Judd Hollow (CR). PMu is bounded by the S-ue surface. Not shown in this cross-section, elsewhere westward the S-ue surface is overlain by the Crystal Creek Member of the Carmel. The upper Page (PUl and PUu, or the leche-e member of Blakey et al., 1996) consists of compound cross-strata not addressed in this study. The upper Page was completely transgressed and is overlain by younger members of the Carmel. 

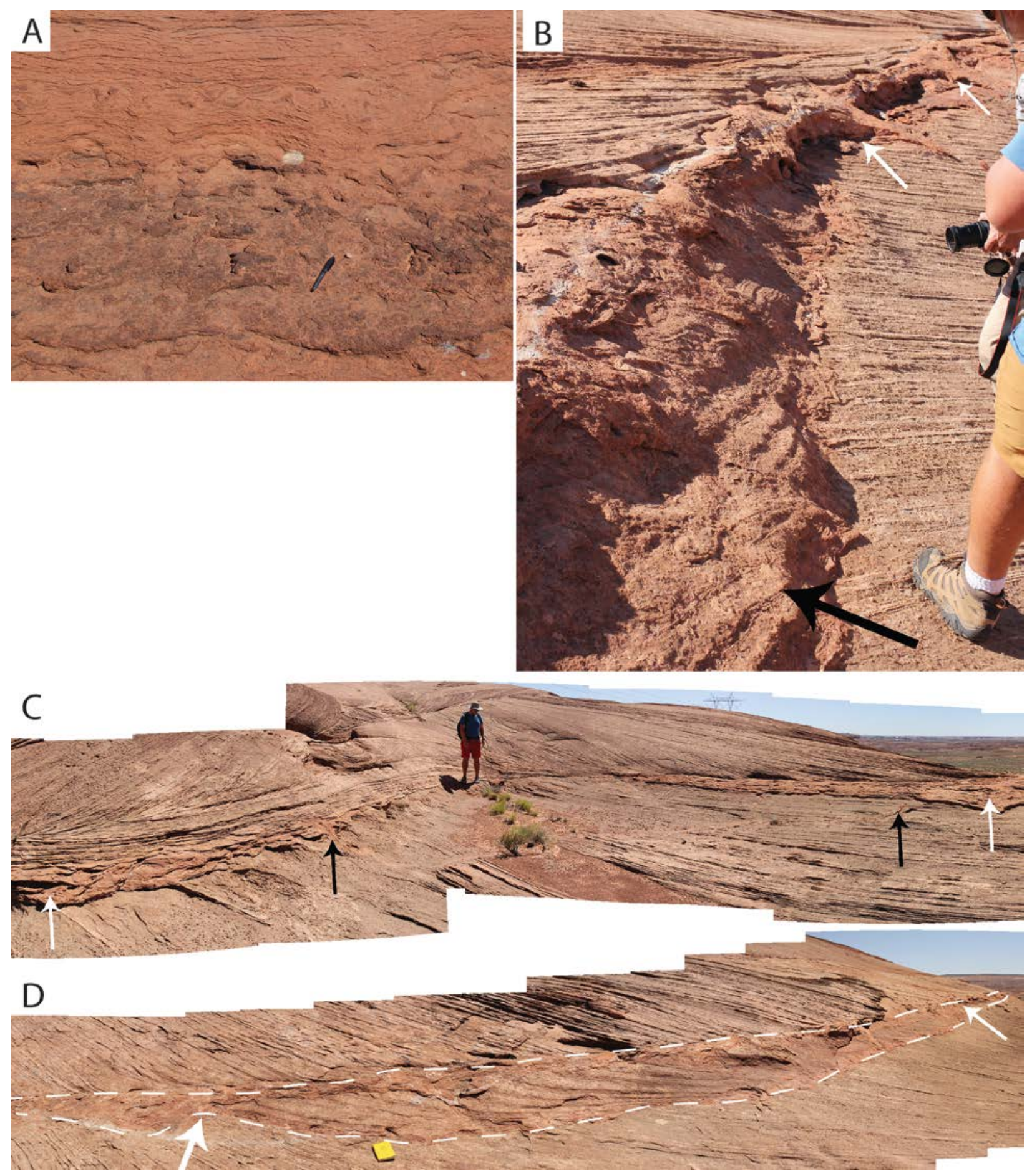

Figure $2(18.2 \mathrm{~cm}$ x $20.8 \mathrm{~cm})$ - A: Contorted sandstone beds interpreted as sabkha deposits. Pen for scale. B: Black arrow points to a thick sabkha deposit along an outcrop-scale bounding surface separating sets of cross-strata. Associated polygonal fractures are visible in the 
background (white arrows). C: An outcrop-scale bounding surface with variably-thick sabkha deposits. White arrows show the locations with the thickest sabkha deposits. Thickness thins to zero at the person. Black arrows point to polygonal fractures associated with the outcrop-scale bounding surface. From the Ferry Swale outcrop. D: An outcrop-scale bounding surface with a laterally-discontinuous set of cross-strata incorporated into a sabkha deposit (outlined in dashed white lines). White arrows point to the ends of the set of cross-strata. This is an unusual outcrop, and only observed at this location at the Ferry Swale outcrop. Yellow field book for scale. 


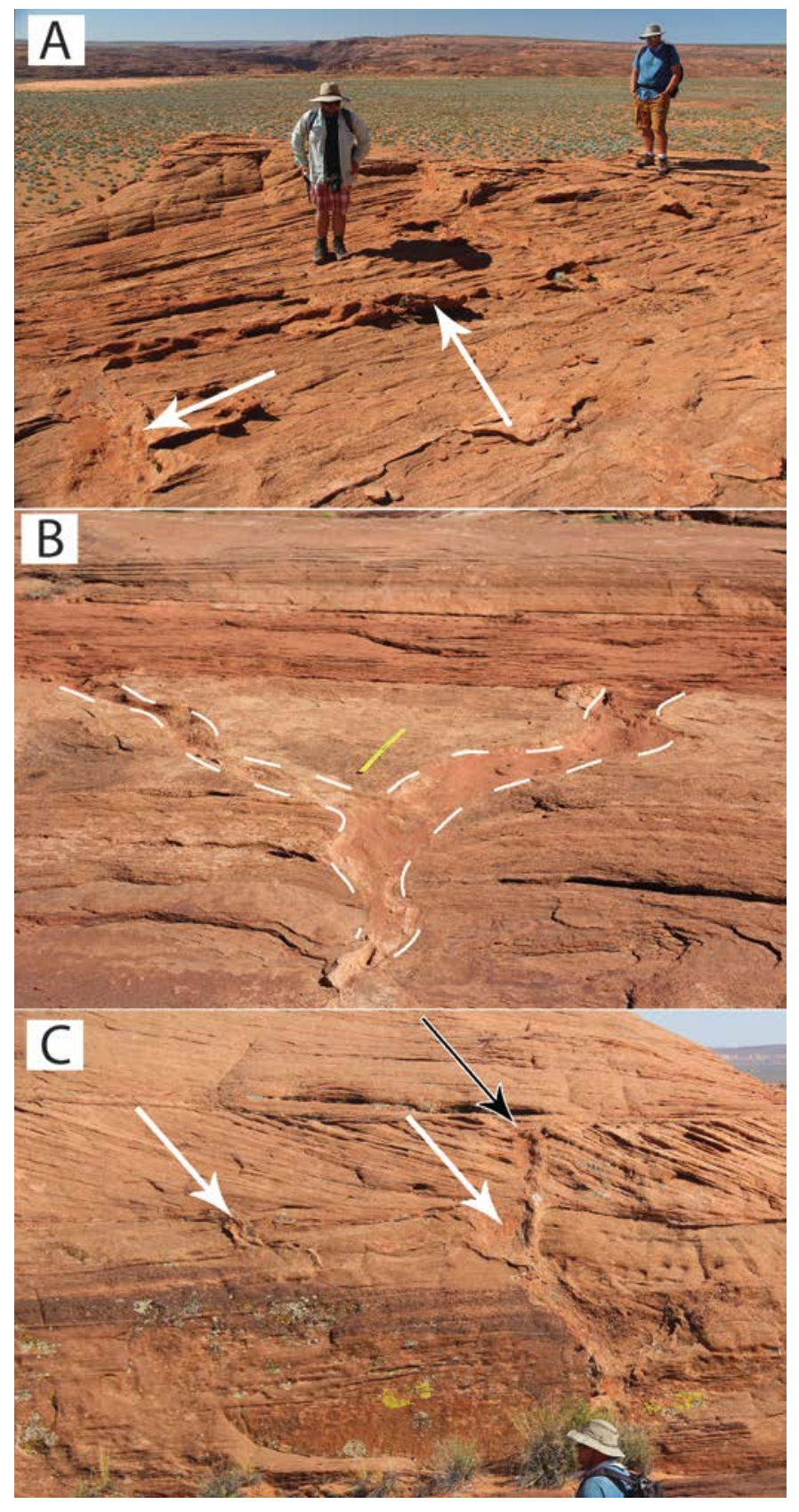

Figure $3(8.8 \mathrm{~cm}$ x $17.0 \mathrm{~cm})$ - Variability of sandstone wedges. A: Topographically-inverted polygonal fractures (white arrows) displaying as raised polygons along a planform exposure of an outcrop-scale bounding surface. B: Two negative relief sandstone wedges intersecting on a shallowly-dipping surface. Wedges are outlined with dashed white lines. Meter stick for scale. C: Sandstone wedges associated with two separate outcrop-scale bounding surfaces at the Ferry 
Swale outcrop (the two laterally amalgamating surfaces pointed out in Fig. 9). The black arrow marks the origin of a sandstone wedge at the higher outcrop-scale bounding surface, which cuts beyond the lower outcrop-scale bounding surface. The white arrows mark the origin of sandstone wedges at the lower outcrop-scale bounding surface. 

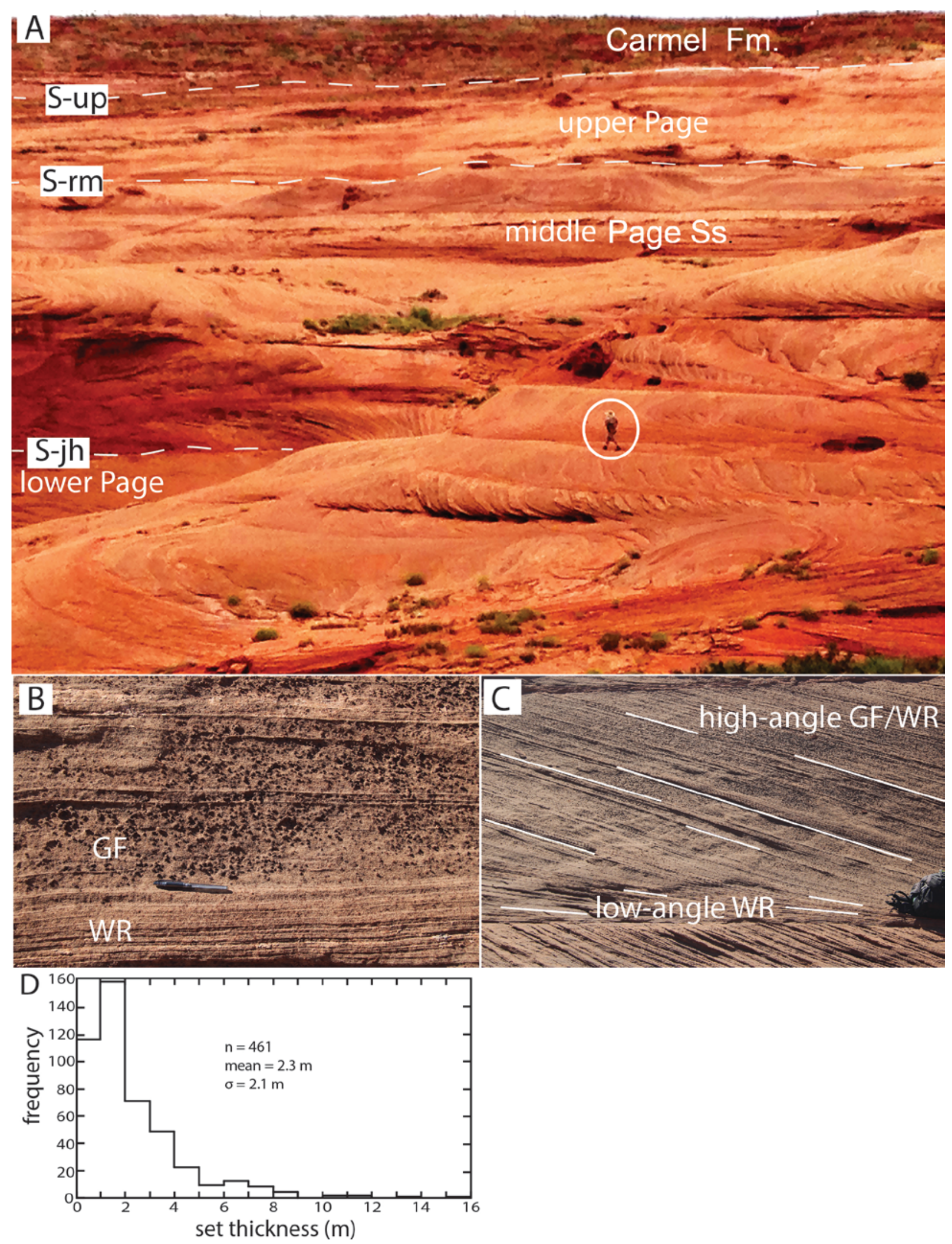
Figure 4 (18.2 cm x $23.2 \mathrm{~cm})$ - A: Typical cross-strata composing the lower and middle Page Sandstone. The Carmel Formation is marked on this photograph. Person for scale is circled. Photograph from the Ferry Swale outcrop. Contrast is stretched to highlight set boundaries and cross-strata in the foreground. B: Planform view of typical arrangement of stratification types in sets of the lower and middle Page. Amalgamated grainflow strata (GF) alternate with wind-ripple laminations (WR). Individual grainflow deposits in these packages are generally not identifiable. Rough texture is from concretions frequently associated with the grainflow strata, but not the wind-ripple laminations. Pen for scale. C: High-angle cross-strata composed of alternating textured grainflow strata and wind-ripple laminations transitioning into low-angle wind-ripple strata near the lower bounding surface. Selected cross-strata are mapped in white to highlight this transition. Backpack for scale. D: Histogram showing the high variability of set thicknesses in the lower and middle Page, with respect to the mean. 

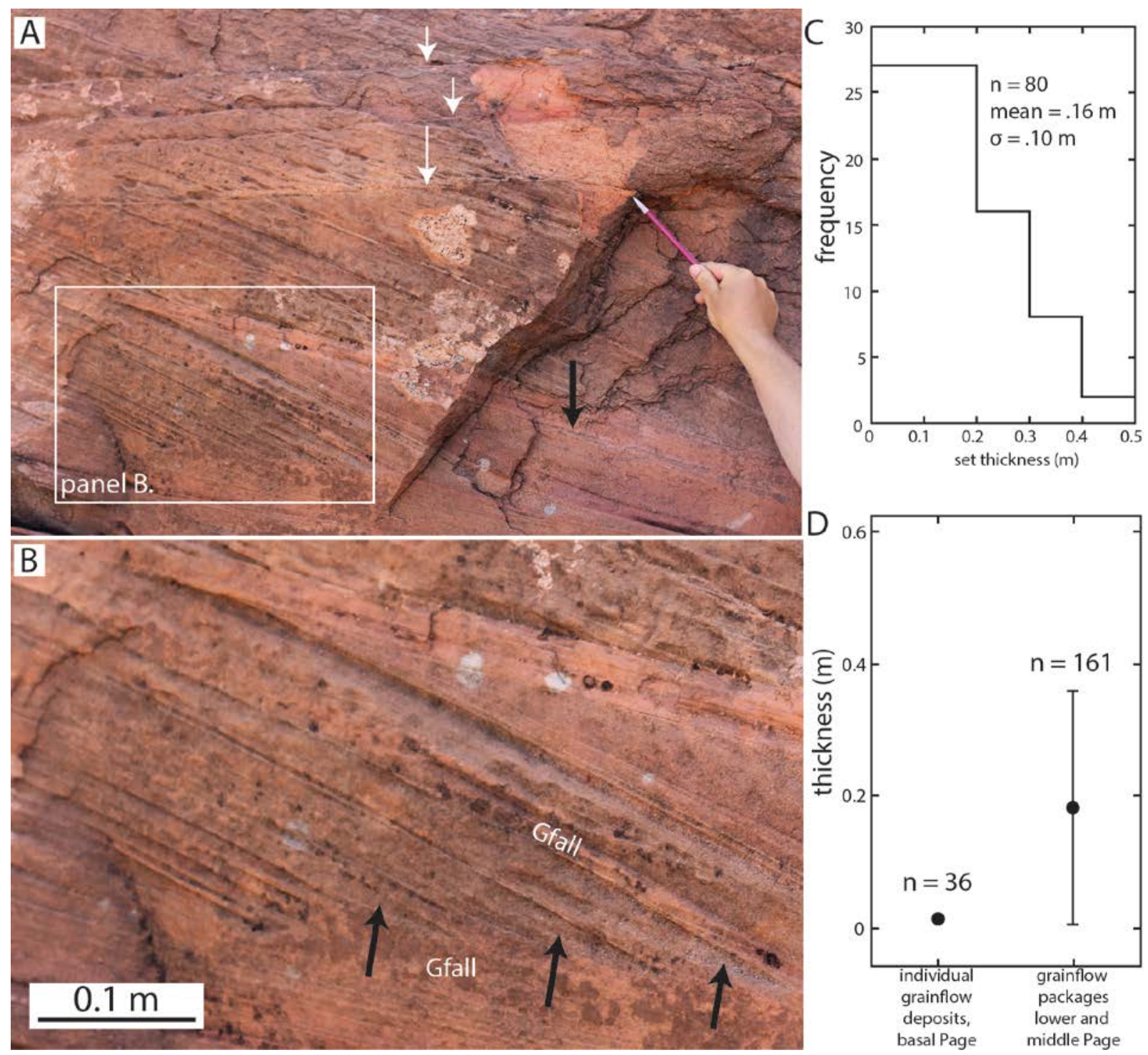

Figure $5(18.2 \mathrm{~cm} \times 16.3 \mathrm{~cm})$ - A: Close-up of the basal Page sets of cross-strata at the Golf Course outcrop. White arrows point to set bounding surfaces. The black arrow points to a reactivation surface within the set, representing a period of lee face erosion bound by packages representing lee face deposition. The deposit is composed of sets averaging $0.16 \mathrm{~m}$ in thickness with individual grainflow deposits separated by thin, tabular beds interpreted as grainfall deposits .The location of panel B is shown with the white box. Pencil for scale. B: A zoom in to part of panel A. Unlike the lower and middle Page sets, individual grainflow deposits are 
identifiable. Black arrows point to the bottoms of grainflow deposits featuring the characteristic blade shape. Finer-grained grainfall deposits are labeled between and at the base of grainflows, and help distinguish the coarser-grained grainflow deposits. C: Histogram showing the thickness distribution of the thin sets in the basal Page, which is tighter than the distribution of lower and middle Page sets. D: Plot comparing the means (circles) and the standard deviations (bars) of thicknesses of individual grainflow deposits in the basal Page to the lower and middle Page. The standard deviation of the basal Page is within the size of the circle. 

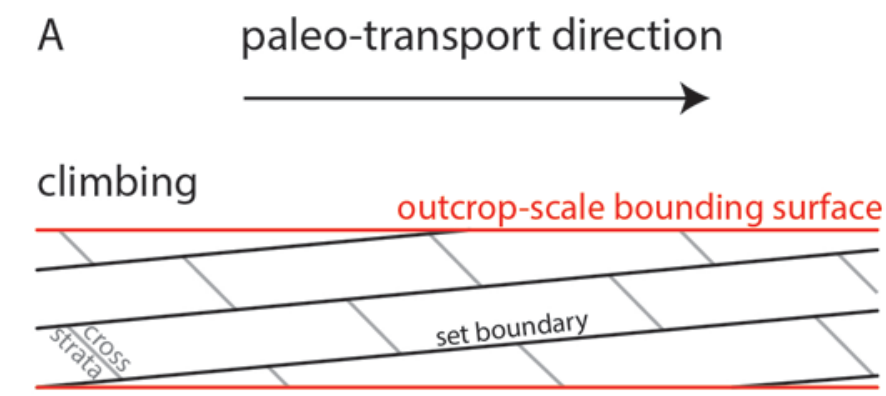

downlapping

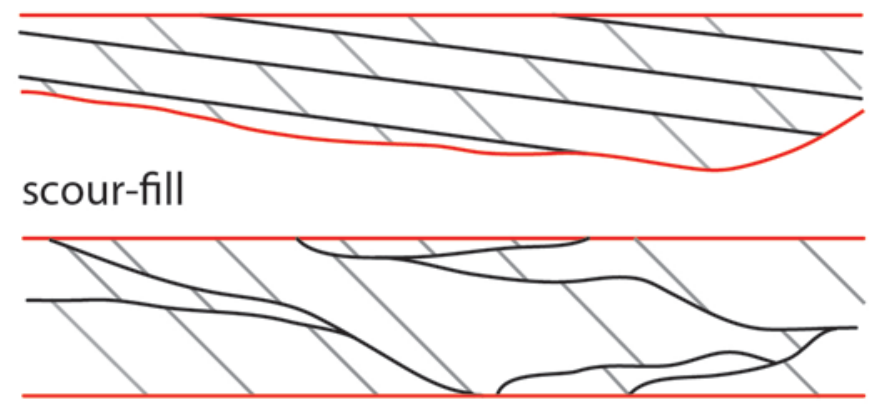

B

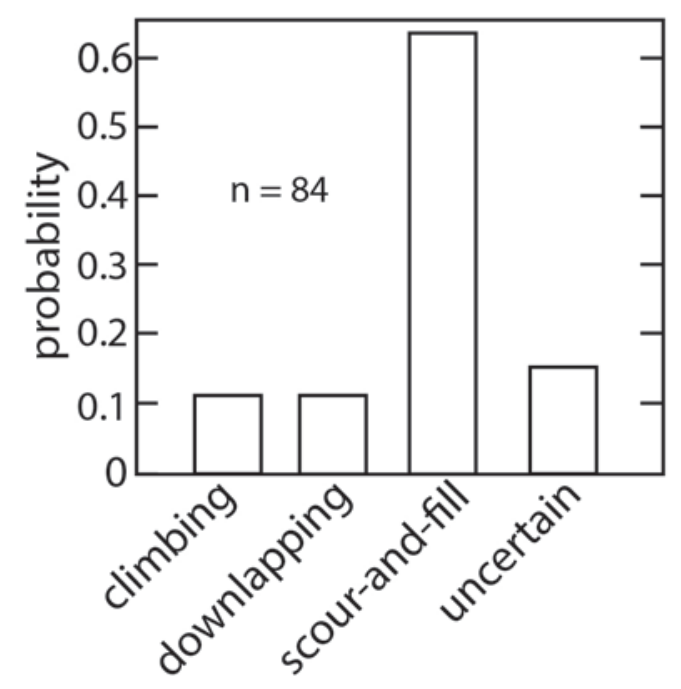

Figure $6(8.8 \mathrm{~cm} \times 16.2 \mathrm{~cm})$ - A: Set architectures of aeolian cross-strata. The black arrow at the top indicates paleo-transport is from left to right in each case. Cross-strata, set boundaries, and outcrop-scale bounding surfaces are all indicated and consistent between diagrams. Some vertical exaggeration is used to accentuate boundary dips. B: Histogram showing the occurrence of architecture types in the Page Sandstone. The most frequently observed geometry is scour- 
and-fill. This analysis does not include the western wall of Ferry Swale (Fig. 8) because it is perpendicular to transport direction and does not fit the models in panel A. 


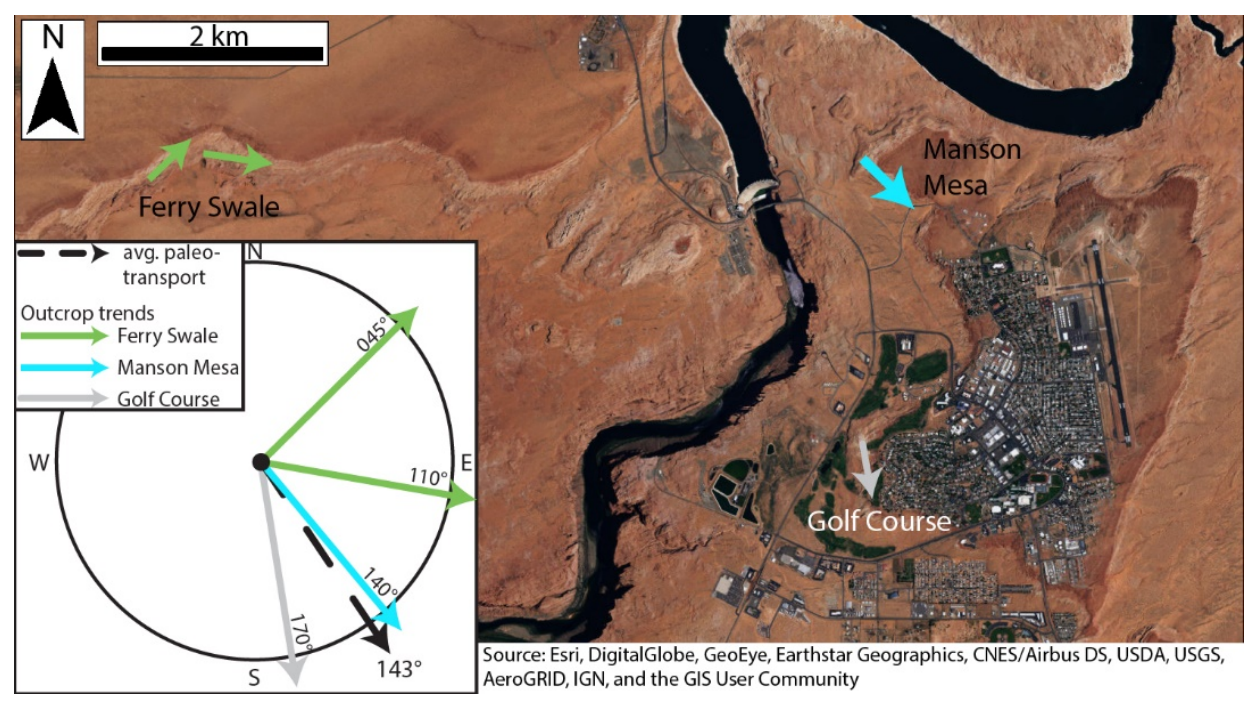

Figure $7(12.5 \mathrm{~cm}$ x $6.9 \mathrm{~cm})$ - Study area near Page, Arizona, marked by the black star in Figure 1. The three outcrops are labeled as Ferry Swale, Manson Mesa, and Golf Course. The associated arrows (green, teal, and white) give the general trends of the outcrop walls, as well as the trends used to create the cross-sections (Figs. 8-9 and S1-S3). In the bottom left corner, the trends of those walls are compared to the average paleo-transport direction within the Page (black dashed arrow; $n=90)$. The western wall of the Ferry Swale outcrop is perpendicular to the average paleo-transport direction, the eastern wall of the Ferry Swale outcrop is oblique, and the Manson Mesa and Golf Course outcrops are near parallel to paleo-transport. 


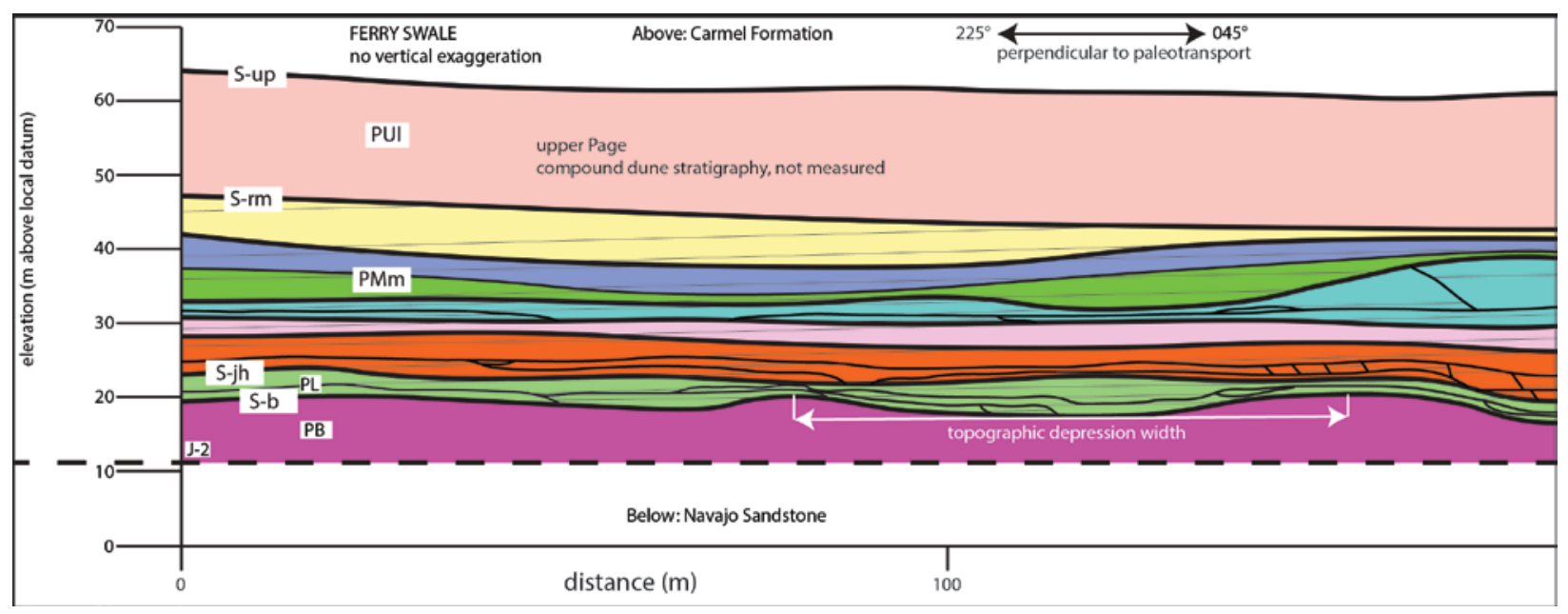

Figure 8 (Landscape, $23 \mathrm{~cm}$ x $8.8 \mathrm{~cm}$ ) - Excerpt of the perpendicular-to-transport wall of the Ferry Swale cross-section (Fig. S1). Location shown in Figure 7. There is no vertical exaggeration. Outcrop-scale bounding surfaces are represented by bold black lines separating outcrop-scale packages of cross-strata of different colors. Black lines within outcrop-scale packages represent cross-set bounding surfaces. Dipping gray lines represent the apparent dip direction of the mean Page transport direction. Colors are used to identify packages of crossstrata separated by outcrop-scale surfaces, and the colors do not necessarily represent correlations between outcrops. The major surfaces are S-up, S-rm, S-jh, and S-b from Havholm et al. (1993). Informal Page units are composed of one to several outcrop-scale packages separated by the outcrop-scale surfaces, and are labeled as in Havholm et al. (1993): PB (basal Page), PL (lower Page), PMm (middle middle Page), and PUl (lower upper Page). The PUl, colored peach, is composed of compound dune deposits, and not studied here. The basal Page (PB) is preserved above the J-2 at this location, and pinches out toward the east (Fig. 9). It is not uncommon for an outcrop-scale package to be composed of one to a few sets, and to vary in number of sets and set thickness laterally. Outcrop-scale bounding surfaces have meters of relief 
at this location. The width of a scallop in outcrop-scale bounding surface relief is demonstrated with white double-headed arrow. 


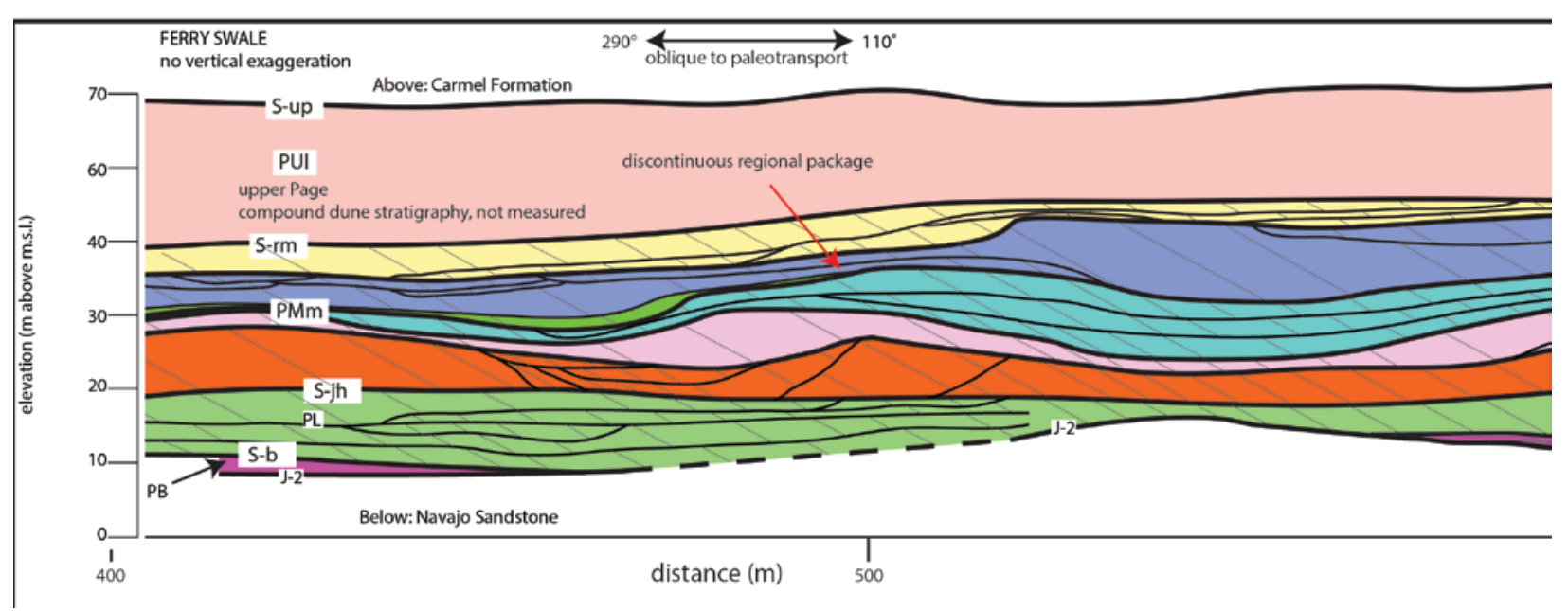

Figure 9 (Landscape, $23 \mathrm{~cm}$ x $8.8 \mathrm{~cm}$ ) - Excerpt of the near oblique-to-transport wall of the Ferry Swale cross-section (Fig. S1). Location shown in Figure 7. Symbology is the same as in Figure 8. Toward the western portion of this section, the basal Page (PB) pinches out along the rising J-2 surface. East of that point, the lower Page sits directly upon the J-2 surface. The location of amalgamation between two outcrop-scale packages is shown with a red arrow. Note the scalloped shape of the outcrop-scale surfaces and the variability in set thickness and discontinuity of sets. 


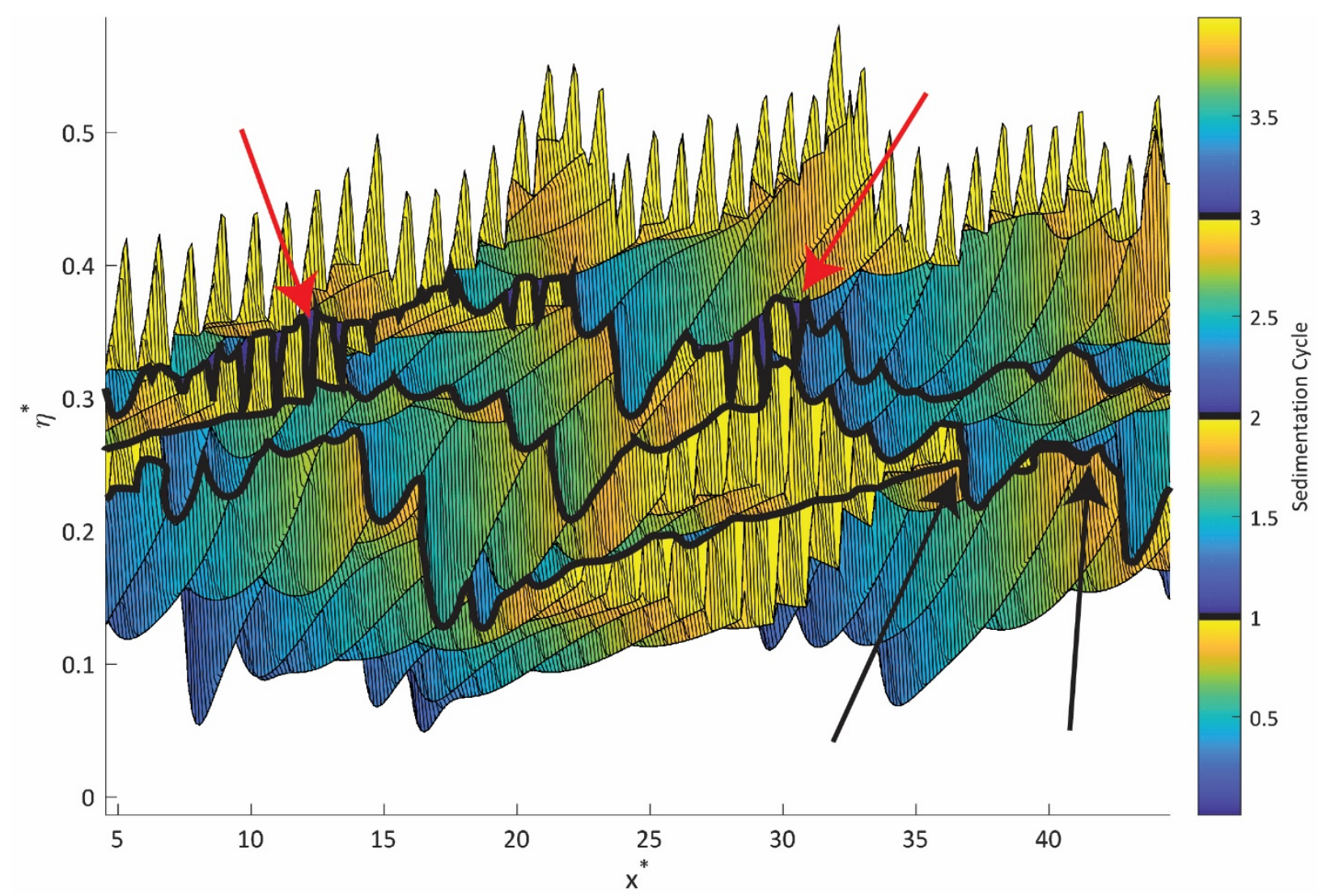

Figure $10(18.2 \mathrm{~cm}$ x $12.2 \mathrm{~cm})$ - Synthetic stratigraphy of Page-type scour-and-fill aeolian accumulation from the model of this paper's companion (Swanson et al. this issue) (model parameters listed in Table S1). Distance and height are expressed in dimensionless values scaled by equilibrium dune wavelength (x-axis) and equilibrium dune height (y-axis). Three water-table highstands are modeled by creating flat, erosional surfaces at progressively higher elevations between episodes of aeolian sedimentation. Following each water-table highstand, a new iteration of the dune field develops. The boldest black domain-scale lines identify three outcropscale bounding surfaces associated with the highstands. The next thickest black lines represent set bounding surfaces. Thin black lines represent the cross-strata. Colors within each outcropscale package represent the relative accumulation time of the deposit, with dark blue representing earliest-phase accumulation and light yellow representing latest-phase accumulation. Scours tend 
to preserve strata associated with the cutting dunes and cannibalize early-phase dune field accumulations, hence the absence of significant dark blue accumulations. Red arrows point to examples of a topographically-low dark blue regions representing the earliest-phase fill of antecedent topography. Conceptually, these locations function as an analog to the fill of antecedent J-2 topography by sets accumulated during early phases of the dune field (Fig. 11AD). In the modeled scenarios, the scour of these accumulations is most frequently performed during later phases of the same sedimentation cycle. Black arrows point to the local amalgamation of two domain-scale bounding surfaces. 

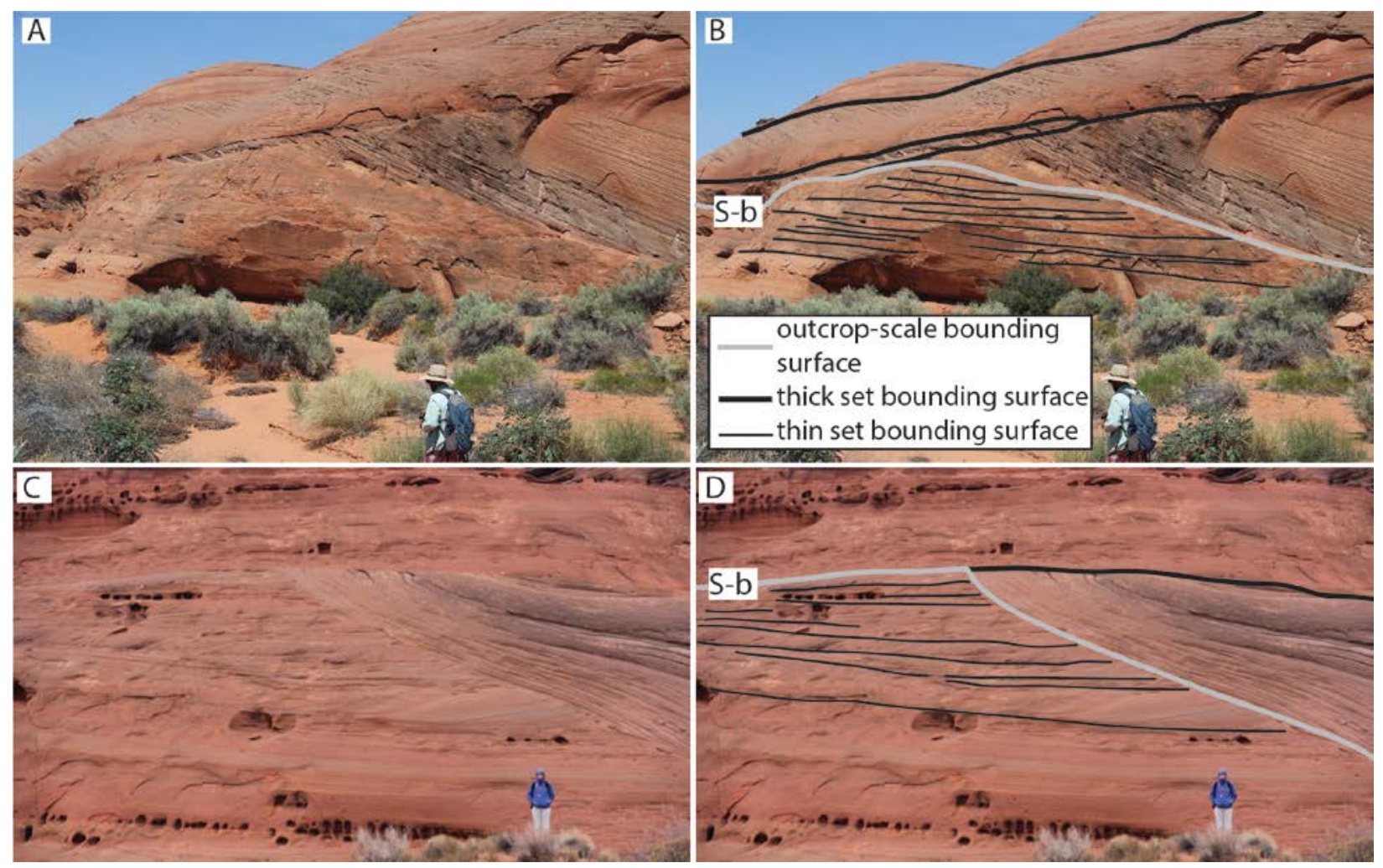

Figure 11 (selected as the color figure for print, $18.2 \mathrm{~cm} \mathrm{x} 11.4 \mathrm{~cm}$ ) - A: This location is $100 \mathrm{~m}$ north of the Golf Course outcrop. About $5 \mathrm{~m}$ of vertical section composed of stacked, relatively thin sets interpreted as basal Page (Fig. 5A-B) truncated by the scour associated with the lower Page. B: Interpreted photograph with the S-b outcrop-scale bounding surface, bounding surfaces of large sets of cross-strata, and bounding surfaces of thin sets of cross-strata mapped. Basal Page is an interpretation, as there is no local exposure of J-2 relief. C: Ferry Swale outcrop. Stacked sets of thin basal Page cross-strata truncated by a scour into the S-b during a later episode of sedimentation. This location is above a $10 \mathrm{~m}$ depression in J-2 relief (location in Fig. S1). D: Selected bounding surfaces superimposed onto the photograph. Key is the same as in panel B. 

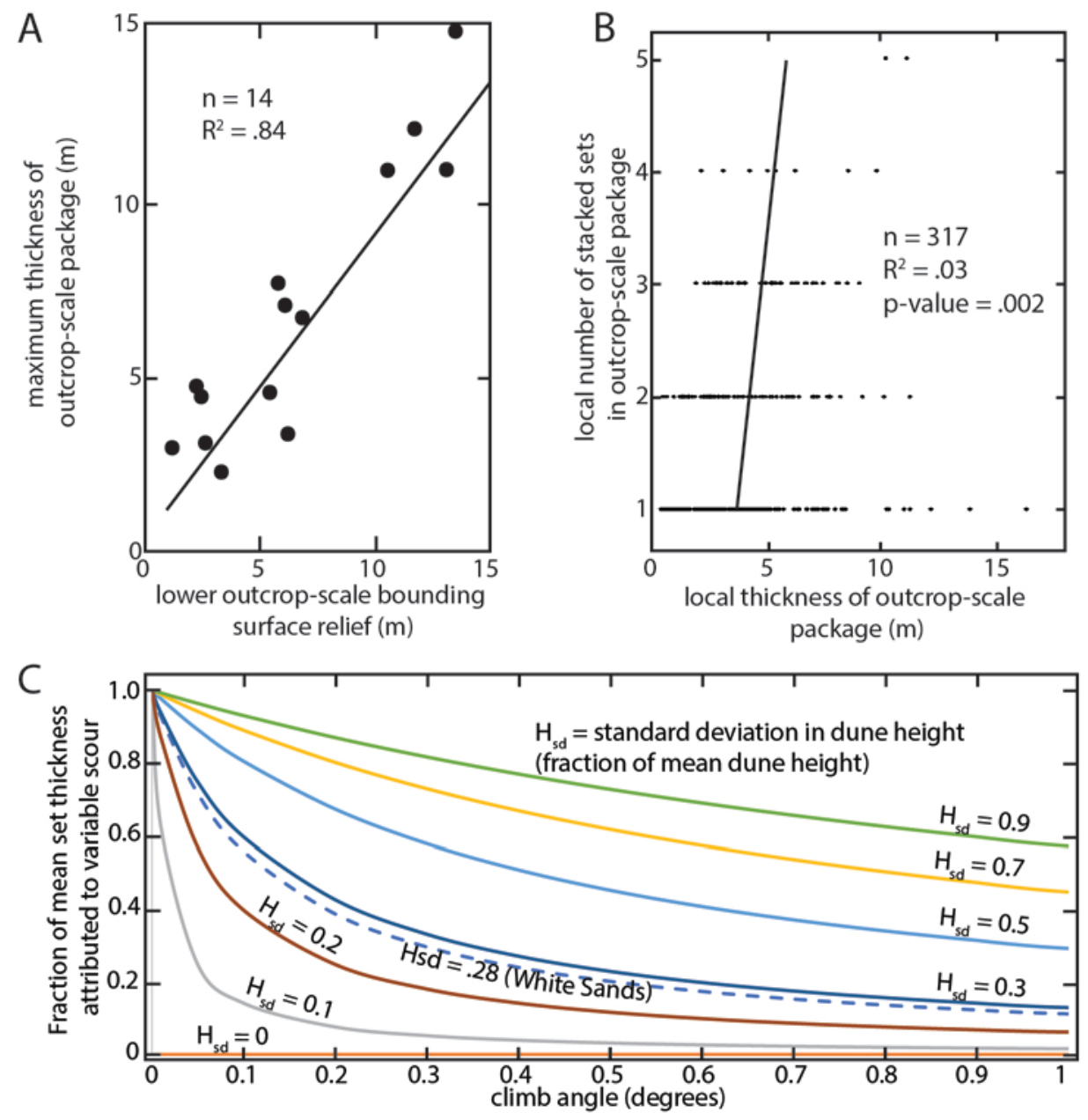

Figure $12(12.5 \mathrm{~cm}$ x $12.8 \mathrm{~cm})$ - A quantification of set architecture composing outcrop-scale packages. Interpretations of the trends are in the Discussion section. A: Total relief along an outcrop-scale bounding surface plotted against the maximum thickness of the outcrop-scale package above the measured surface. The linear fit is significant, indicating that basal relief controls the preserved thickness of the package. B: The number of sets bound by adjacent outcrop-scale bounding surfaces at a given location plotted against the thickness of the package at that same location. The best fit linear trend is not significant, indicating that the number of sets does not control the package thickness. C: Climb angle plotted against the contribution of variable scour to the mean set thickness based on the standard deviation of dune height. Colored 
lines represent different standard deviations in dune size. At low climb angles, variation in dune height and the subsequent variation in dune scour depths are a dominant control on mean set thickness. An increase in climb angle and/or a decrease in the standard deviation of dune sizes decreases the effect of variable scour on mean set thickness. The fraction of set thicknesses attributed to variable scour depth is calculated for White Sands based on information in (Baitis et al. 2014). Calculated from Bridge and Best (1997) using mean height and celerity values of dunes at White Sands (Baitis et al. 2014). 


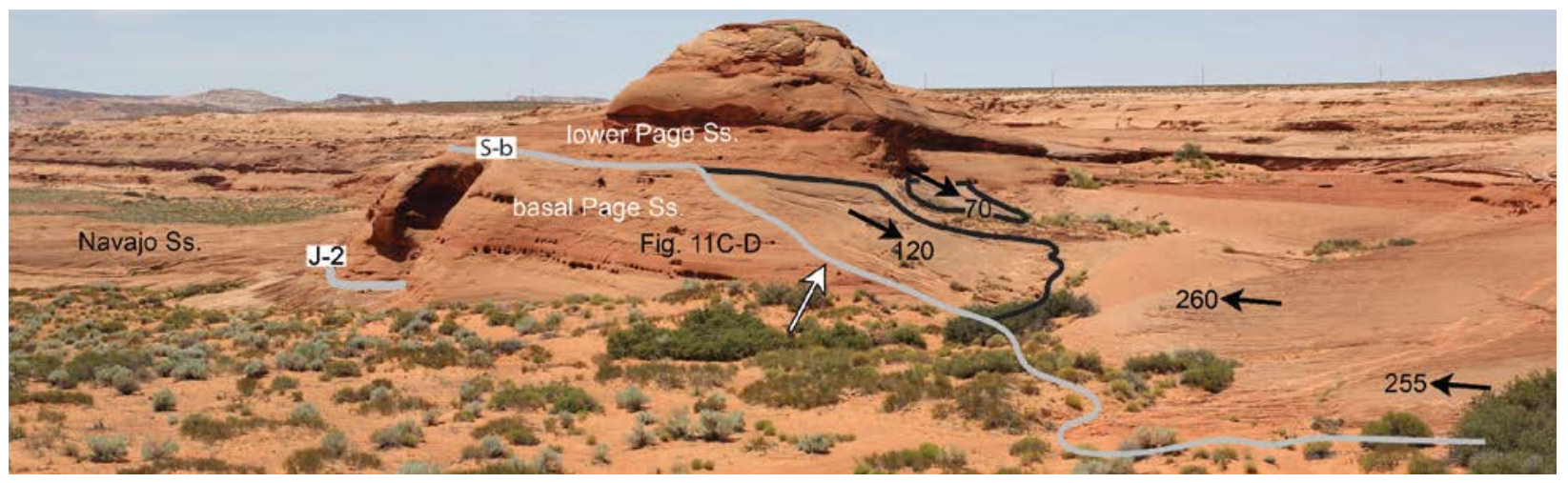

Figure $13(18.2 \mathrm{~cm}$ x $5.5 \mathrm{~cm})$ - Location featuring a topographic depression in the J-2 surface at Ferry Swale, and a subsequent partial scouring of early-phase basal Page accumulations (Fig. S1). The J-2 is mapped with a thick black line, separating the Navajo from the basal Page. Scour surfaces bounding thick grainflow deposits are mapped with thinner black lines. Black arrows show cross-strata dip directions. The stacked thin sets shown in Figure 11C-D are labeled, and are truncated by a scour into the S-b surface dipping towards $120^{\circ}$. Adjacent grainflow strata dip toward $70^{\circ}$. Wind-ripple strata dip towards $260^{\circ}$ and $255^{\circ}$, nearly $180^{\circ}$ different than the grainflow strata and over $100^{\circ}$ different from the regional average transport direction. The center location is interpreted as the deepest portion of a lower Page scour into the S-b surface that partially cannibalized early-phase basal Page. 

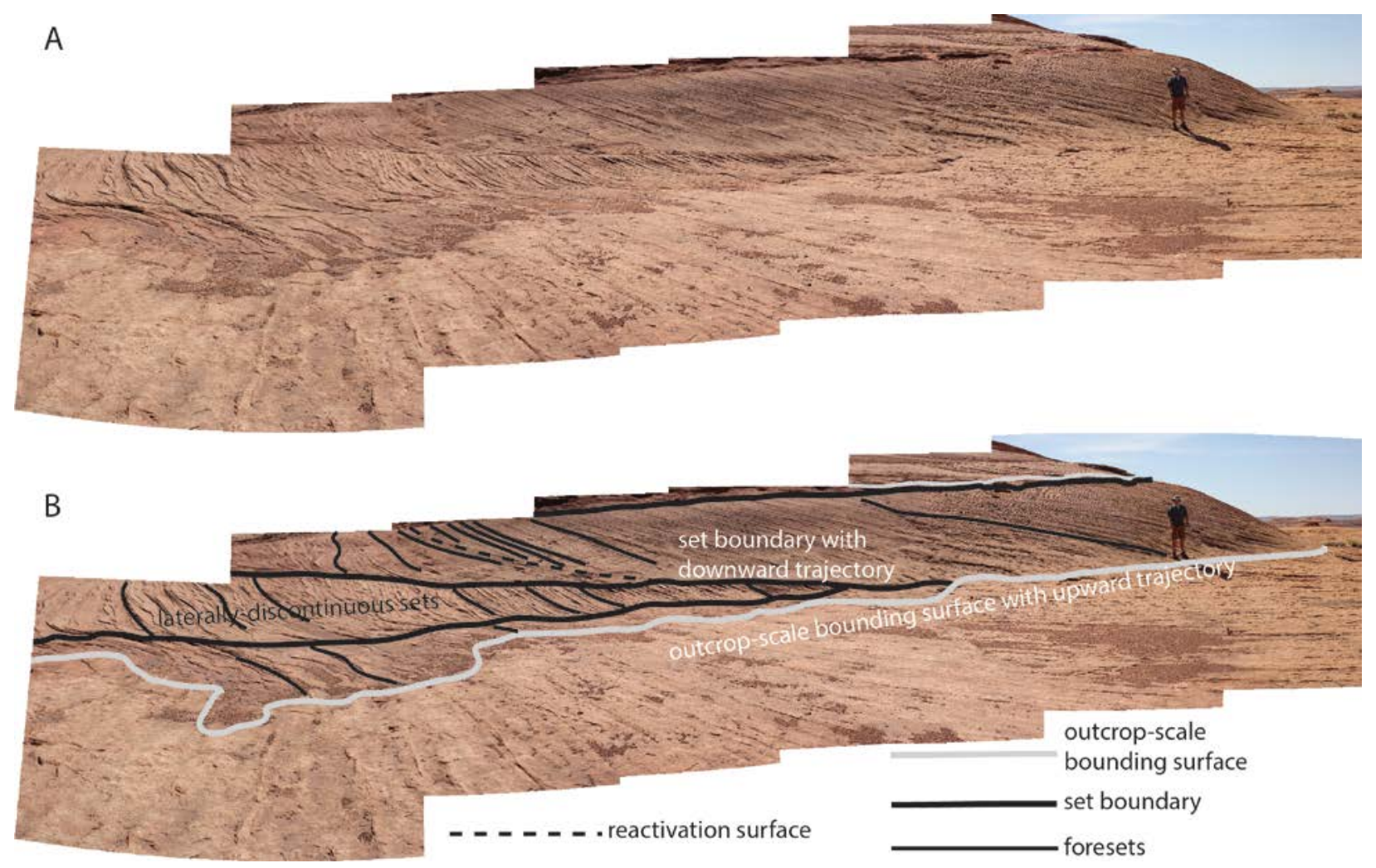

Figure 14 (Landscape, $23.2 \mathrm{~cm} \mathrm{x} 14.6 \mathrm{~cm}$ ) - A: A set of cross-strata with a lower bounding surface with a downward trajectory, truncating two lower sets of cross-strata within the same outcrop-scale package. B: Interpreted panorama with mapped outcrop-scale bounding surfaces, set bounding surfaces, and a reactivation surface, which represent a period of lee face erosion between periods of lee face deposition. This serves as an example of a scour-and-fill geometry, variable set thickness, and an entire outcrop-scale package defined by only 2-4 stacked sets. 
SUPPLEMENTARY MATERIALS FOR:

\title{
PRESERVATION OF AUTOGENIC PROCESSES AND ALLOGENIC FORCINGS WITHIN SET-SCALE AEOLIAN ARCHITECTURE II: THE SCOUR-AND-FILL DOMINATED JURASSIC PAGE SANDSTONE, ARIZONA, USA
}

\author{
BENJAMIN T. CARDENAS ${ }^{1}$, GARY KOCUREK ${ }^{1}$, DAVID MOHRIG ${ }^{1}$, TRAVIS \\ SWANSON $^{2}$, CORY M. HUGHES ${ }^{1 *}$, and SARAH C. BROTHERS ${ }^{1 * *}$ \\ ${ }^{1}$ Jackson School of Geosciences, University of Texas at Austin, Austin, TX, USA \\ ${ }^{2}$ Department of Earth Science, Rice University, Houston, TX, USA \\ *now at Department of Geology, Western Washington University, Bellingham, WA, USA \\ ${ }^{* *}$ now at National Academies Space Studies Board, Washington, D.C., USA
}



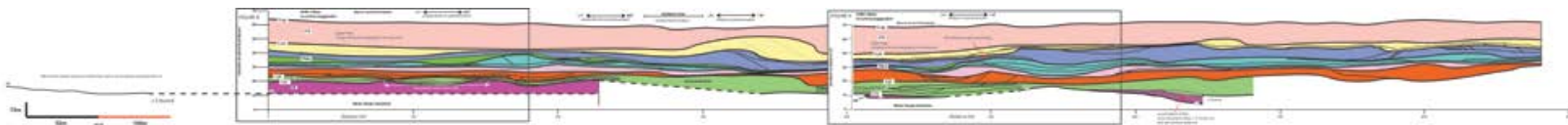

Figure S1 (124.5 cm x $9.5 \mathrm{~cm}$ - This will need to be a separate PDF) - Complete cross-section of the Ferry Swale outcrop, including a change in outcrop orientation (location shown in Fig. 7). There is no vertical exaggeration. Outcrop-scale bounding surfaces are represented by bold black lines separating outcrop-scale packages of cross-strata of different colors. The major surfaces among those are labeled S-up, S-rm, S-jh, and S-b (Havholm et al., 1993). Thinner black lines within outcrop-scale packages represent cross-set boundaries. Dipping gray lines represent the apparent dip direction of the mean Page paleotransport direction. The colors used to separate outcrop-scale packages do not represent correlations between outcrop-scale packages shown in Figs. S2 or S3. Informal Page units are composed of one to several outcrop-scale packages separated by the outcrop-scale surfaces, and are labeled as in Havholm et al. (1993): PB (Basal Page), PL (lower Page), PMm (middle middle Page), and PUl (lower upper Page). The PUl,

24 colored peach, is composed of compound dune deposits, and not studied here. Part of the basal 25 Page exposed to the west of the panel and not analyzed here is composed of alternating sabkha and cross-sets. This package of PB is locally preserved above the $\mathrm{J}-2$, and pinches out towards the east.

27 A section of PB exposed towards the east contains the thin, stacked sets shown in Figures 11C-D and 13. It is not uncommon for an outcrop-scale package to be composed of one to a few sets; the

29 pink outcrop-scale package is used as an example. Outcrop-scale bounding surfaces have meters 30 of relief at this location. The width of a scallop in outcrop-scale bounding surface relief is 31 demonstrated with white text and a white double-headed arrow. The outcrop-scale relief of the J322 surface is shown. The J-2 is at its highest elevation at the westernmost part of the panel, and at 
33 its lowest exposed elevation beneath the thin, stacked sets. The locations of Figures 8 and 9 from

34 the main text are shown.

35

36

37

38

39

40

41

42

43

44

45

46

47

48

49

50

51 


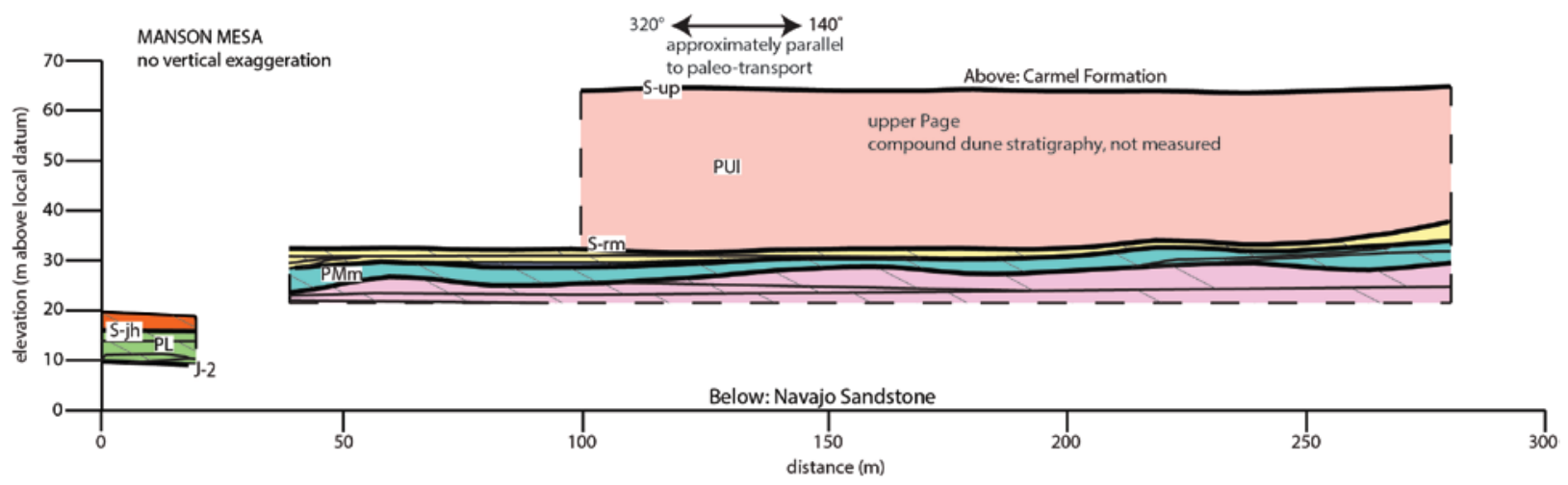

53 Figure S2 (landscape $23.2 \mathrm{~cm} \times 7.1 \mathrm{~cm}$ ) - Projected cross-section of the parallel-to-transport

54 Manson Mesa outcrop (location shown in Figure 7). Symbology is the same as in Figure S1. Sets

55 are more laterally continuous at this location, and there is less relief along outcrop-scale surfaces

56 than at Ferry Swale. Exposures of lower Page and S-jh at the left of the panel become vertical

57 towards the right, and eventually are buried, and as such are not continuously surveyed.

58

59

60

61

62

63

64

65

66

67

68 


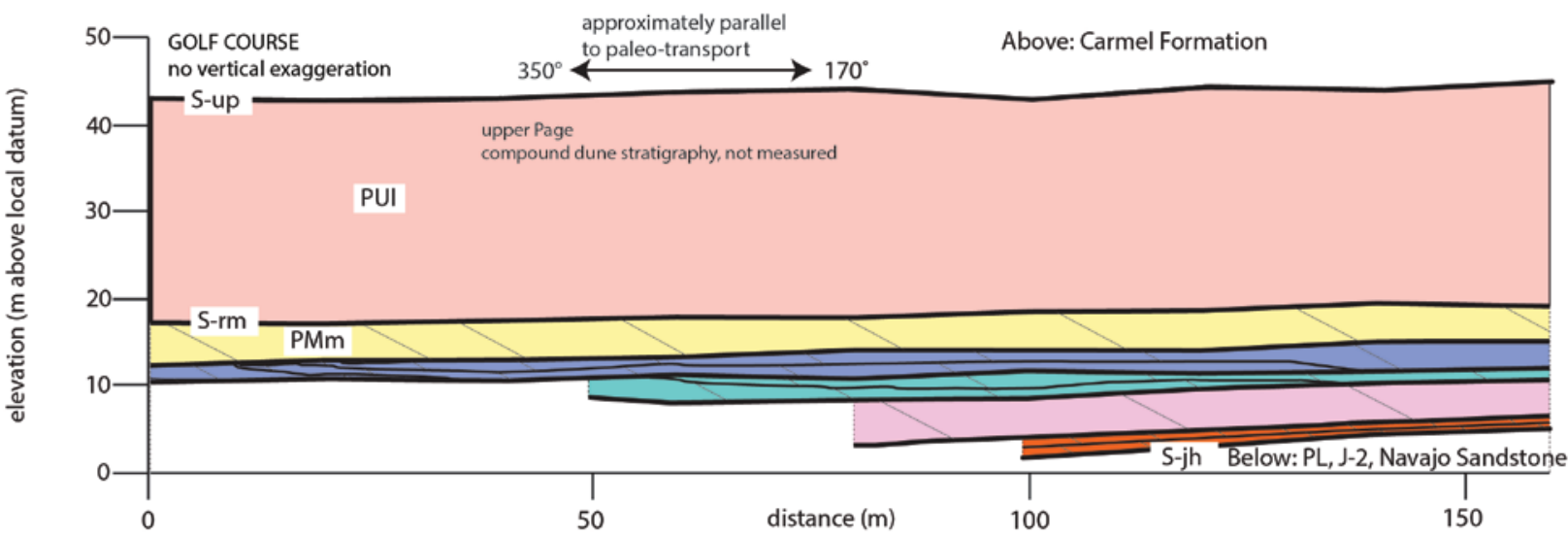

71 Figure S3 (landscape $23.2 \mathrm{~cm} \mathrm{x} 7.7 \mathrm{~cm}$ ) - Projected vertical section of the parallel-to-transport

72 Golf Course outcrop (location shown in Figure 7). Symbology is the same as in Figure S1. Like

73 the Manson Mesa outcrop, sets are more continuous and there is less relief along outcrop-scale

74 surfaces compared to Ferry Swale. The vertical wall exposing a package of thin sets is 150 meters

75 north of this location (Fig. 11A-B).

76

77

78

79

80

81

82

83

84

85

86 
87 Table S1- Parameters used in the numerical model (Fig. 10). Parameters are discussed in detail in

88 a companion paper (Swanson et al. this issue). Units are arbitrary.

89

90

91

92

93

94

95

96

97

98

99

100

101

\begin{tabular}{|c|l|l|}
\hline Parameter & Value & Description \\
\hline$A$ & 0.1 & Flow blocking parameter \\
\hline$B$ & 3 & Flow shoaling parameter \\
\hline$m$ & 1 & Meyer-Peter and Müller coefficient \\
\hline$n$ & 1.5 & Meyer-Peter and Müller coefficient \\
\hline$E$ & 20 & Avalanching coefficient \\
\hline$D$ & 0.2 & Diffusivity \\
\hline$p$ & 0.4 & Bed porosity \\
\hline$\tau_{a}$ & 0.3 & Ambient shear stress \\
\hline$r_{a}$ & $1 E-4$ & Bed aggradation \\
\hline$\Delta t$ & 1 & Model timestep \\
\hline$\Delta x$ & 10 & Node spacing \\
\hline$\Delta w t$ & .5 & Vertical distance ascended by water table \\
& & following each deposode \\
\hline & & \\
\hline
\end{tabular}

102 